\title{
Cold Acid Postmortem Blood Most Probably Formed Pinkish-Red Heme-Madder Lake on Madder-Dyed Shroud of Turin
}

\author{
Adrie A. M. van der Hoeven \\ Utrecht, The Netherlands \\ Email: a.v.d.hoeven@hetnet.nl
}

Received 8 October 2015; accepted 27 November 2015; published 30 November 2015

Copyright (C) 2015 by author and Scientific Research Publishing Inc.

This work is licensed under the Creative Commons Attribution International License (CC BY). http://creativecommons.org/licenses/by/4.0/

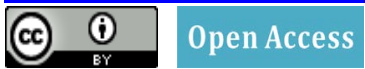

\begin{abstract}
The Turin Shroud was extensively scientifically investigated in 1978. In its pinkish red bloodstains, normal features of human blood were found, but also seemingly anomalous ones. In the present study, hitherto unnoticed details of the data are presented, Shroud data and more modern reference data are compared, and the results of a few experiments with linen, madder dye and blood are shown. It turns out that the Shroud's 'anomalous' data are strong consistent evidence that its bloodstains contain acid heme-madder lake, of which the heme derived from cold acid postmortem blood and the madder had been applied to the Shroud at manufacture. It implies that the bloodstains were formed on the Shroud before the still not reproduced body-image was. Several other 'red-color' hypotheses for the Shroud's bloodstains are discussed and dismissed.
\end{abstract}

\section{Keywords}

Turin Shroud, Blood, Madder, Forensic Medicine, Spectroscopy

\section{Introduction}

The Shroud of Turin is a $4.4 \times 1.1 \mathrm{~m}$ linen cloth that is kept in Turin, Italy, and that is at least six centuries old and bears the frontal and dorsal image of a man and apparent bloodstains in the areas of the hands, feet, side, head, and small of back, and also burn holes and scorch marks and water stains and creases (see e.g. [1]). It is believed by many to be the burial cloth of Jesus Christ. In 1978 a multidisciplinary group of scientists, among which many of the Shroud of Turin Research Project (STURP), examined the cloth using several methods among which UV-vis, UV-fluorescence and X-ray fluorescence spectrometry and later their samples were also subjected to FT-IR spectrometry and other tests. It was found that the bloodstains on the Shroud show a number 
of normal human blood features such as the presence of red blood cells [2]-[4], hemoglobin [4] [5], porphyrin [3] [6] [7], iron [8], serum albumin [7], primate immunoglobin [3] [9] [10], and erythrocyte antigens A and B [3]. However, also a number of anomalies were found: most bloodstains are pinkish-red, as seen in the color-calibrated photos made in 2008 [11] (Figure 1), their UV-vis spectra lack a Soret peak [12], X-ray fluorescence failed to detect potassium in the red stains [8], microscopy showed only very few red blood cells [2] [13], and the FT-IR spectra of loose "blood globs" from the Shroud are not typical of dried blood [14]. The survival—and even splendid condition — of the cloth and its bloodstains after at least six centuries of microbial attack also is exceptional. As the Turin Shroud is not accessible for hands-on scientific research at the moment, this study sought to find an explanation of these anomalies by a detailed analysis and comparison of available data, the testing of hypotheses against these data, and the performance of a few experiments to physically test some hypotheses, especially the only remaining plausible one. In this manner, this paper presents a new and consistent explanation of the anomalies that also accounts for the observed anomalous fluorescence of the cloth [15] and for the FT-IR spectra of samples from various non-image areas [16] [17]. The three new concepts that together constitute this explanation are that the Shroud bloodstains contain a pinkish-red complex of acid heme dimers and madder (Section 2), of which the acid heme dimers derived from cold acid postmortem blood (Section 3), and of which the madder was already uniformly present on the Shroud since it was starched and dyed with yellow acid madder dye at manufacture (Section 4). A few experiments show how cold blood clots can imprint Shroud-like pinkish stains and fluorescent serum margins on starched and madder-dyed linen (Section 5).

\section{Bloodstains Contain Madder Lake}

\subsection{UV-Vis Spectra of Red Blood Material}

Three kinds of blood material were subjected to UV-vis spectrometry. The first was a microscopic red-brown translucent crystal that, while still stuck to the sticky-tape by which it had been lifted from the surface of the Shroud, yielded a clear Soret peak at 405-410 nm in UV-vis transmission, and which further UV-vis spectrum was not published but led to the identification of "old acid methemoglobin" ([9] p. 147). The second kind were 6 $\mathrm{mm} \times 3 \mathrm{~mm}$ areas of bloodstains on the cloth. Their UV-vis reflectance spectra were ratioed to those of clear background areas of the Shroud, and four of the resulting relative reflectance spectra were then averaged to obtain the mean relative reflectance spectrum of the bloodstains. All four published bloodstain spectra plus the mean reflectance spectrum (Figure S1) [12] show a broad, more or less flat band from ca. 340 to $525 \mathrm{~nm}$ with no suggestion of a Soret band, an absorbance peak at ca. $630 \mathrm{~nm}$, and especially the mean reflectance spectrum also shows small bands at $280 \mathrm{~nm}$ and $725 \mathrm{~nm}$. The absorbance peak at ca. $630 \mathrm{~nm}$ could be interpreted as the charge transfer peak of acid methemoglobin (cf. Figure S2) [18], but the lack of a clear Soret peak was studied further by Pellicori [19]. He found that much of the clear contrast of a Soret peak, measured in transmission mode, is

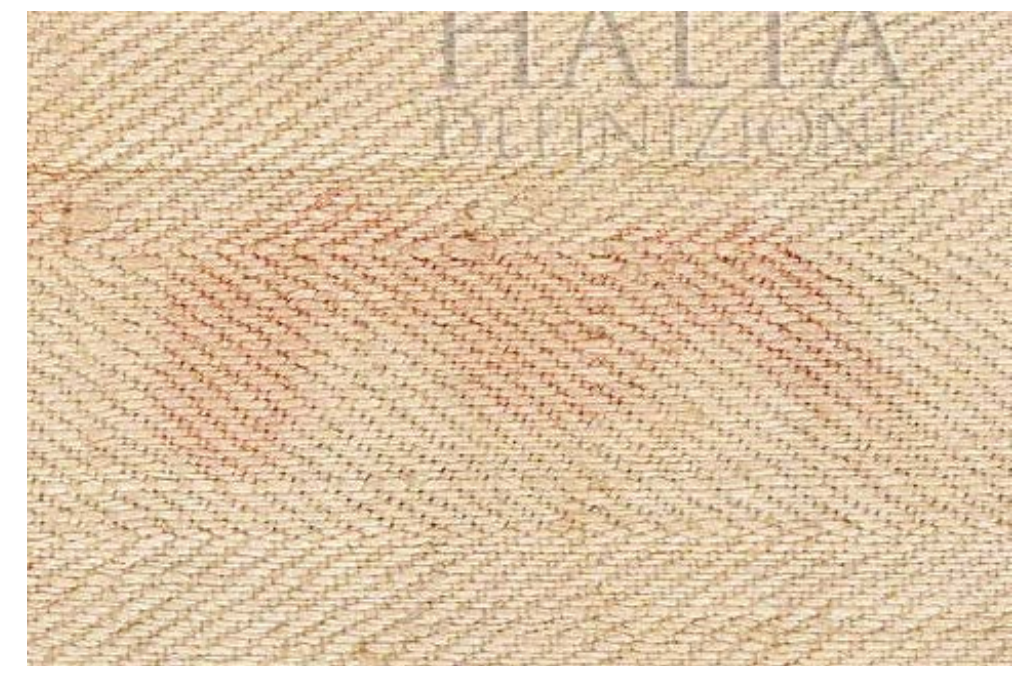

Figure 1. Bloodstain in forehead area of the Shroud. Color-calibrated photo by Haltadefinizione ${ }^{\circledR}$ Image Bank [11]. Copyright Arcidiocesi di Torino. 
lost when measured in reflectance mode, and that ageing of bloodstains on linen also reduces the contrast of the Soret peak (Figure S3). The third kind of red material were microfibers with red stains on part of their length, also still stuck to their sampling sticky-tape. A UV-vis absorbance curve from ca. 405 to $650 \mathrm{~nm}$, measured in transmission, of one of these fibers shows a clear peak at ca. $450 \mathrm{~nm}$ with a ca. $530 \mathrm{~nm}$ shoulder, but no (charge transfer) peak at ca. $630 \mathrm{~nm}$ (Figure S4) [6].

As bilirubin, a substance which concentration in the blood is elevated in a heavily traumatized body, has a broad absorbance peak at ca. $450 \mathrm{~nm}$, Adler hypothesized, until his death in 2000, that the presence of a very high bilirubin level in the blood caused both the disappearance of the Soret peak in the mean bloodstain spectrum and the appearance of the high peak at $450 \mathrm{~nm}$ in the fiber spectrum [13] [15]. However, the UV-vis spectrum he published of a mixture of whole blood and bilirubin in albumin [14] is unlike either of the above mentioned Shroud blood spectra, and there are many other contradictive arguments and characteristics of the Shroud blood materials (Section 2.4 and Section 4.10).

In 2006, a new type of blood product was discovered: the aqueous heme $\pi-\pi$ dimer [20]. It is a product of acid denaturation of (met) hemoglobin and has a Soret band at 340 - $400 \mathrm{~nm}$ that is rather flat and much smaller than in acid methemoglobin or in hemichrome [21] or even in free heme or in the heme $\mu$-oxo dimer, also in comparison to the $500 \mathrm{~nm}$ peak, especially at low (acid) pHs, and it has a small band at ca. $725 \mathrm{~nm}$ (Figure S5 and Figure S6). When in acidic conditions, e.g. at $\mathrm{pH} \mathrm{5.5,} \mathrm{it} \mathrm{would} \mathrm{also} \mathrm{have} \mathrm{the} \mathrm{charge} \mathrm{transfer} \mathrm{peak} \mathrm{at} 630 \mathrm{~nm}$ (pers. commun., 25-07-2013, with the corresponding author of [20]). The near flatness of the mean reflectance spectrum of the Shroud bloodstains from 340 to $525 \mathrm{~nm}$ therefore can be explained by the presence of this acid heme dimer plus the presence of yellow acid madder dye, absorbing at $450 \mathrm{~nm}$, and pink/red madder lake, absorbing at $525 \mathrm{~nm}$ and $280 \mathrm{~nm}$ (cf. Figure S7 and Figure S8) [22] [23]. While the color of madder dye changes with $\mathrm{pH}$ - this is its acidichromism-[24] (Figure S9), the color of a madder lake, i.e., a stable complex of madder dyestuffs and a mordant, is a fixed color and pink when the mordant is iron [25] (Figure S10).

In order to compare the UV-vis spectrum of madder lake in Kubelka-Munk values (k/s) (Figure 2) with the Shroud bloodstain data, the mean relative $\mathrm{k} / \mathrm{s}$ spectrum of the bloodstains is calculated by first multiplying the published mean relative reflectance values of the bloodstains by the published mean absolute reflectance val-

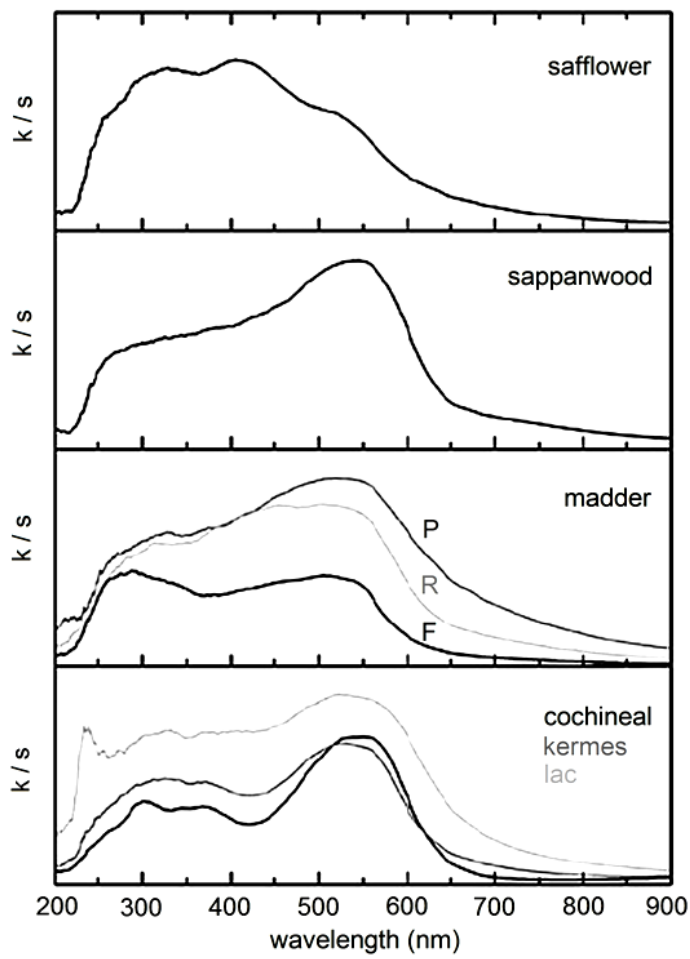

Figure 2. UV-visible absorption spectra of red lakes in Kubelka-Munk (k/s) values; madder $\mathrm{P}=$ prepared from plant root extract, $\mathrm{R}$ and $\mathrm{F}=$ prepared from extract of dyed wool samples. From [147], with permission from Springer Science and Business Media. 
ues of the background areas [12] in order to regain the absolute reflectance values of the bloodstains, and then calculating the $\mathrm{k} / \mathrm{s}$ value

$$
\mathrm{k} / \mathrm{s}=(1-\mathrm{R})^{2} /(2 \mathrm{R})
$$

from these absolute reflectance values $(\mathrm{R})$ for both bloodstain and background, and finally calculating the so-called "percent relative post-color number" (PRO) [26] of their k/s difference relative to the k/s value of the background:

$$
\mathrm{PRO}=100 \times\left(\mathrm{k} / \mathrm{s}_{\text {blood }}-\mathrm{k} / \mathrm{s}_{\text {backgr }}\right) / \mathrm{k} / \mathrm{s}_{\text {backgr }}
$$

In the plot of these calculated PRO values (Figure 3), the $525 \mathrm{~nm}$ peak is dominant, just as in the $\mathrm{k} / \mathrm{s}$ spectra of madder lake (cf. Figure 2 and Figure 3). In the stains' calculated PRO plot the bands typical of acid heme dimers are retained, as is the $450 \mathrm{~nm}$ band assignable to yellow acidic madder dye. Also the ca. $450 \mathrm{~nm}$ and 530 nm peaks in the UV-vis spectrum of the partly red microfiber from the Shroud (Figure S4) can be explained as the $450 \mathrm{~nm}$ absorbance peak of acid yellow madder dye, present all around the fiber, and the ca. $525 \mathrm{~nm}$ absorbance peak of red madder lake, formed where acid heme mordanted the surface of the dye pinkish red and then largely abraded from the microfiber on the Shroud surface. The bloodstains on the cloth, on the other hand, would have retained more blood material between and underneath the surface fibers, while the cloth, which probably was starched before it was dyed (Section 4), also carries relatively less madder dye than a single surface fiber. Before abrasion, the blood deposits on the cloth would have protected the yellow madder dye underneath the deposits from degradation during body-image formation and ageing, which may explain the $450 \mathrm{~nm}$ band in the spectrum of the bloodstains relative to the aged unprotected background.

\subsection{UV Fluorescence of Shroud Bloodstains}

In 1978, UV fluorescence photography of the Shroud was performed with filters that effectively separated the UV excitation (335 - $375 \mathrm{~nm}$ ) from the recorded visible fluorescence ( 410 $\mathrm{nm}$ and higher) [27]. Its report says that, in the obtained photos, the bloodstains look dark compared to the greenish yellow fluorescing background. Yet, some of the bloodstains also look red in fluorescence (e.g. Figure 4 and Figure S11).

Blood is not fluorescent under the applied conditions [28] [29]. Madder lake's maximum fluorescence emission is at ca. $620 \mathrm{~nm}$, in the visible red [30]. The main constituents of a madder root extract are the colorants alizarin and purpurin, in a ratio dependent on the type of madder and the extraction method and further treatment and history [30]. Although the aluminum lakes of alizarin and purpurin show a mutually slightly different fluorescence emission maximum near $620 \mathrm{~nm}$, both alizarin and purpurin lakes have an excitation minimum at ca. $365 \mathrm{~nm}$, exactly in the excitation range used for the UV fluorescence photography in 1978 (Figure S12) [30].

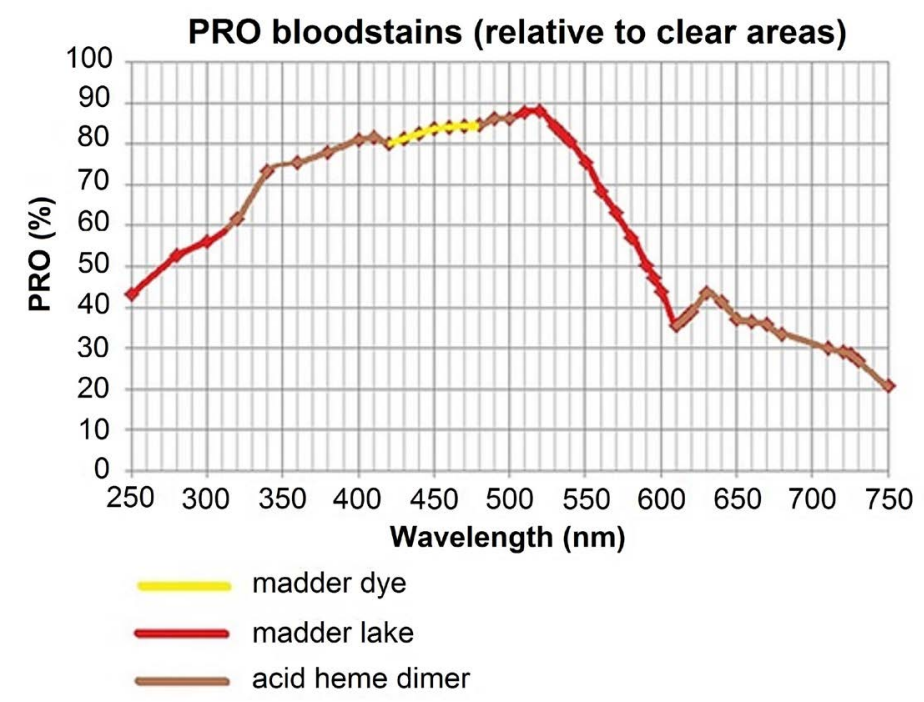

Figure 3. Possible composition of the calculated PRO spectrum (relative absorbance based on k/s values) of Shroud bloodstains relative to background areas of the Shroud. 
This, plus the quenching of any madder lake fluorescence by remaining heme deposits, may explain the darkness of the bloodstains' red fluorescence. Legrand and others have reported that the Shroud's bloodstains, when seen in sunlight, look redder than when seen in the cathedral or behind a glass plate [31]. Sunlight's UV components beyond the mentioned excitation minimum would make madder lake fluoresce more brightly red. As also the fluorimetry of the Shroud was done with $365 \mathrm{~nm}$ excitation [12], a contribution of madder lake's red fluorescence would not have been conspicuous.

Nevertheless, the published fluorescence spectra of the various different areas of the Shroud (e.g. Figure 5) [12] show that, while all spectra are dominated by a ca. $435 \mathrm{~nm}$ band—probably caused by the ca. $435 \mathrm{~nm}$ fluorescence emission of lignin [32] in the linen cloth-, the bloodstains fluoresce redder than the background areas and the image areas: the published fluorescence intensities (F) at $450 \mathrm{~nm}$ and at $600 \mathrm{~nm}$-closest to madder lake's $620 \mathrm{~nm}$ maximum - were read from the spectra and ratioed. The results $\left(\mathrm{F}_{450} / \mathrm{F}_{600}\right)$ are represented in Table $\mathrm{S} 1$ and Figure 6. The smaller ratio-representing a redder color - in the bloodstain fluorescence is thus made clear. The smaller ratio in the scorch areas corresponds to the reported visibly reddish fluorescence of light scorches [27].

\subsection{FT-IR Spectra of Shroud Blood Globs}

In 2002, FT-IR spectra of microsamples from various Shroud areas were published [14]. The three published FT-IR spectra of microscopic particles, called 'blood globs', found on the sticky-tape samples, are quite similar to each other and therefore probably quite reproducible (Figure 7). They are also quite similar to FT-IR spectra of madder lake, both qualitatively (Figure 7 and Figure S13) and numerically; the FT-IR spectrum of heme (Figure S14) [33] also appears to be compatible with the Shroud 'blood globs' FT-IR spectra [34].

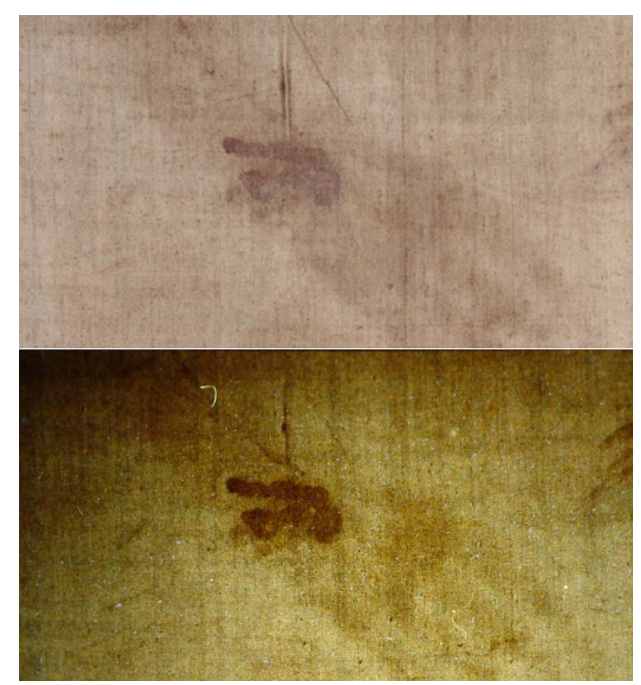

Figure 4. Wrist area of the Shroud in reflected light photo (top, from [1]) and ultraviolet-fluorescence photo (bottom, (C)1978 Vernon Miller, Fair Use).

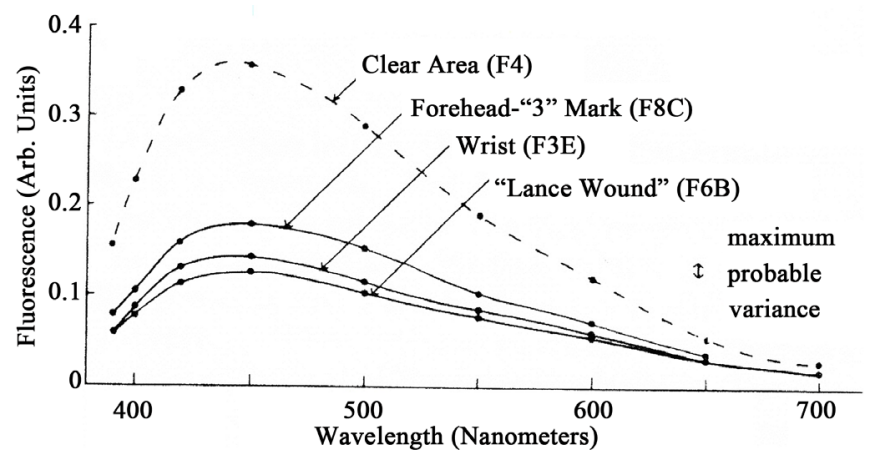

Figure 5. Smoothed fluorescence curves of three bloodstains of the Shroud. From [12]. 


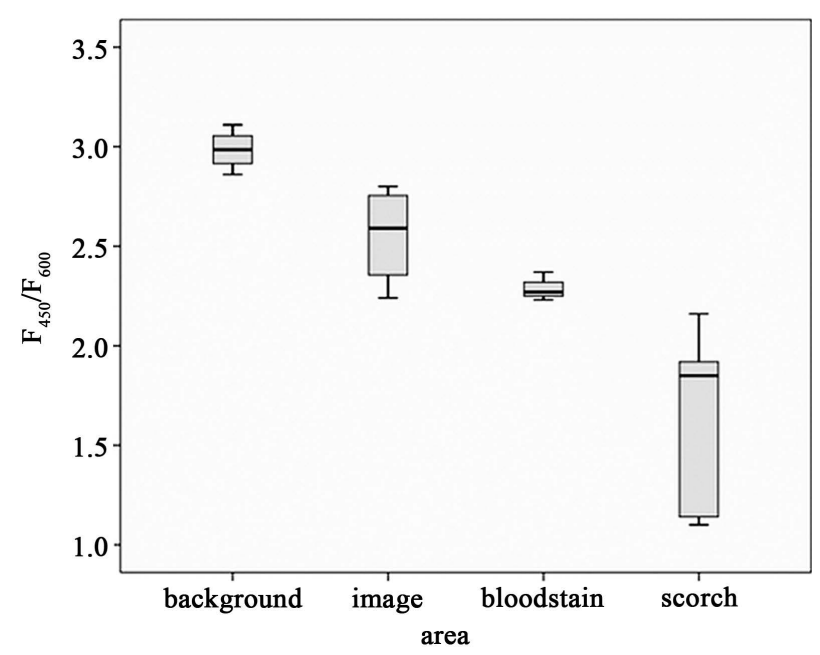

Figure 6. Distribution of the $\mathrm{F}_{450} / \mathrm{F}_{600}$ ratios of fluorescence intensity of Shroud areas listed in Table S1.
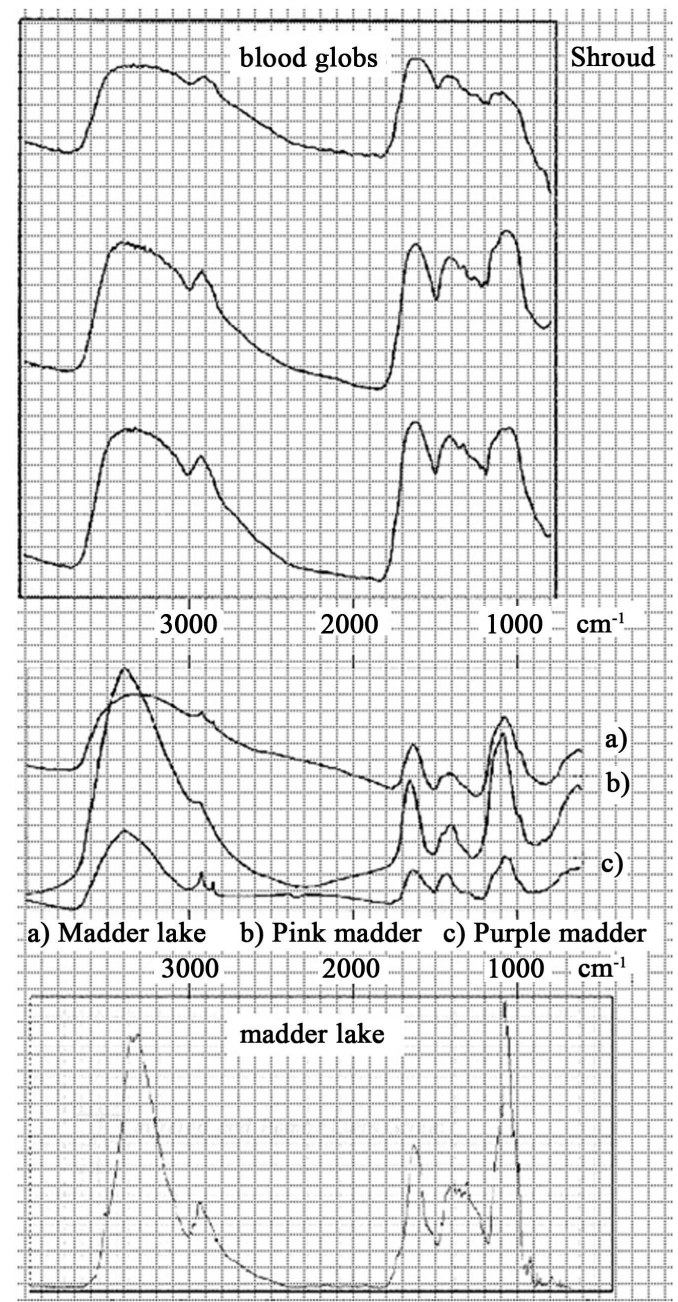

Figure 7. Rough qualitative comparison of FT-IR spectra of Shroud 'blood globs’ (from [14]) and madder lakes, adapted for alignment and covered with lath; centre plot: FT-IR spectra of three madder lakes (from [148] 2011 @John Wiley and Sons); bottom plot: same FT-IR spectrum of madder lake as in Figure S13, but 2013 edition (from [149], with permission from the Infrared \& Raman Users Group). Abscissas: wavenumbers in $\mathrm{cm}^{-1}$. 


\subsection{Not a Bilirubin Excess or Nitrosoheme or CO-ligand or UV-Exposure}

Bilirubin is not light-stable and fluoresces green [35], so could not give bloodstains a stable red color and fluorescence, and would give separate serum a green color, if present at an excess level [31] [36]. In 2002, both a UV-vis and a FT-IR spectrum of a simulation of Adler's hypothesized Shroud blood-made by adding a bilirubin-albumin mixture to whole blood-was published [14]. The UV-vis spectrum is unlike any of the Shroud blood spectra, and qualitatively and numerically the 'simulated' FT-IR spectrum is less compatible with the Shroud 'blood globs' FT-IR spectra than those of madder lake (Figure 8) [34]. This also holds for the FT-IR spectra of nitrosoheme-both fresh and aged by photo-oxidation [33] —, a species that was hypothesized by Berry [37] as having been painted on the Shroud. Also the UV-vis spectrum of nitrosoheme [33] is quite different from that of heme and that of the Shroud bloodstains (Figure S15). CO is not a light-stable ligand to the heme of hemoglobin (Hb) [38] and also the UV-vis spectrum of HbCO is very different from those of metHb or the Shroud [39]. Prolonged UV-irradiation of bilirubin produces lumirubin, which under UV-containing light might give a temporary red color to brown blood (cf. [40]); the lighting of some previously UV-exposed, red-looking, experimental bloodstains produced by Goldoni [31] is not specified [41]. Besides, there are red bloodstains in non-image areas of the front and reverse of the Shroud, and there are a few brown parts of bloodstains right beside red parts on the front.
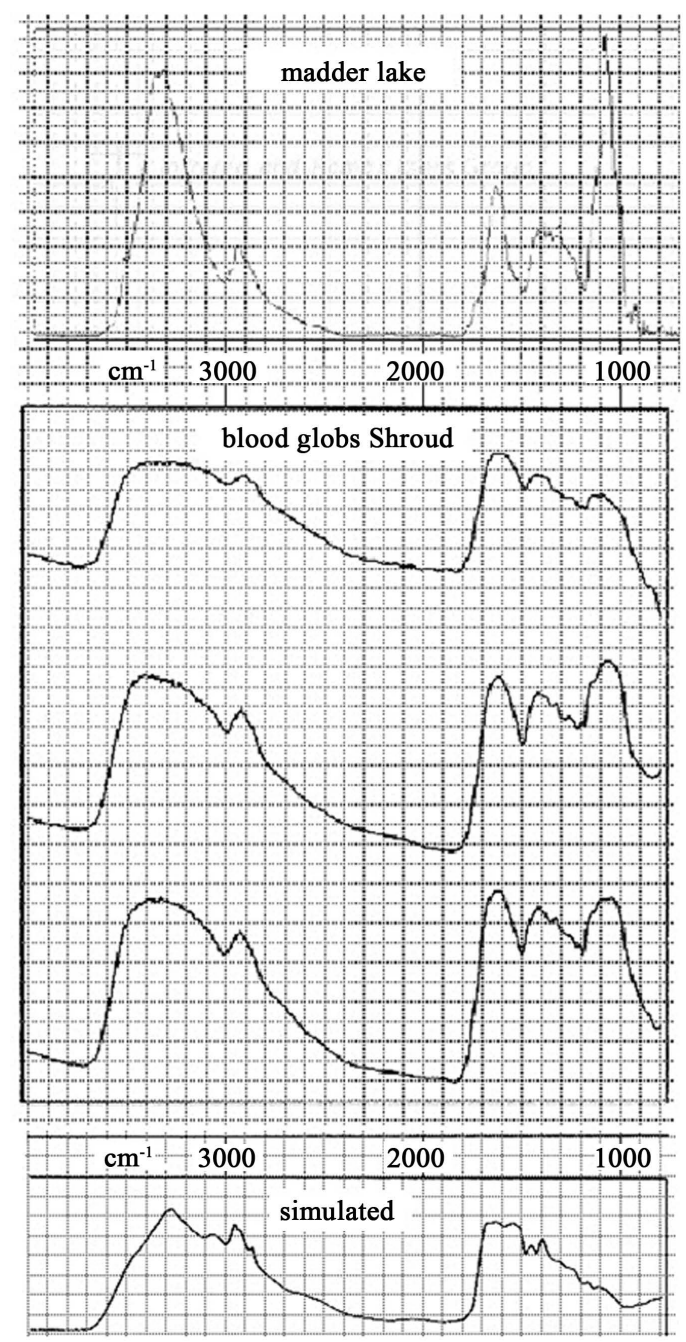

Figure 8. Comparison of aligned FT-IR spectra of madder lake (from [149], with the permission from the Infrared \& Raman Users Group), Shroud 'blood globs', and a 'simulated' blood clot containing extra albumin and bilirubin (from [14]). Abscissas: wavenumbers in $\mathrm{cm}^{-1}$. 


\subsection{Not Painted-On Madder Lake or Red Ochre}

From this comparison of UV-vis, fluorescence and FT-IR data can be concluded that the most probable main constituent of the pinkish red bloodstains on the Shroud is a heme-madder lake formed from acid heme. The element iron was easily found in Shroud bloodstains by X-ray fluorescence spectrometry [8] and also in Shroud blood samples analyzed by Energy dispersive spectrometry (EDS), which found only very little aluminum there [6] [42]-[44]. The hypothesis that, for creating all bloodstains, a red iron-madder lake-or red ochre plus vermillion [44] — was painted on, cannot account for the bloodstains' $630 \mathrm{~nm}$ peak in UV-vis (cf. Figure 5 of [45]), nor for the mentioned normal blood features found on the Shroud (Section 1). The sources for the heme-madder lake's constituting acid heme and madder dye most probably were acid postmortem human blood (Section 3) and a madder-dye coating on the cloth (Section 4).

\section{Cold Acid Postmortem Blood Caused Bloodstains}

\subsection{Blood pH below 6.8}

Blood of a healthy person has a $\mathrm{pH}$ near 7.4, but in a person suffering from acidemia the blood $\mathrm{pH}$ is lower (the blood is more acidic). Acidemia can be caused by strenuous exercise and cramping, dehydration, respiratory failure or a prolonged agonal state [46] [47]. A blood $\mathrm{pH}$ below 6.8 is incompatible with life [48]. After death, blood rapidly becomes more acidic; e.g., a blood $\mathrm{pH}$ of 5.5 has been measured in a dead human body 20 hours postmortem [47] [49]. The UV-vis spectra of the Shroud bloodstains are compatible with their formation from liquid or wet postmortem acid blood as the observed pronounced charge transfer peak at $630 \mathrm{~nm}$ is only present when the $\mathrm{pH}$ of the solution is below 6 (Figure S1 and Figure S2) [18], and 'Soret-peak-lacking' heme dimers are also only formed from an aqueous methemoglobin solution by acid denaturation at a pH below 6.8 [50]. In a dry methemoglobin film, on the other hand, its heme moieties - even after losing their connection with their surrounding globins due to ageing - cannot move to form heme dimers. Also the presence of an acid methemoglobin crystal on the Shroud can only be explained by the formation of the crystal from a drying acid solution.

\subsection{X-Ray Fluorescence Spectra of Bloodstains Lack Potassium}

The potassium that is present in normal whole blood predominantly resides inside the red blood cells. In acidemia, however, the potassium level in the red blood cells gradually decreases relative to its level in the blood plasma [51]. After death, potassium precipitously moves out of the cells, also in blood, where it moves into the plasma [52]. The potassium serum level even gets very high so quickly that it cannot be used as a measure for the length of the postmortem time interval in forensic investigations [53].

Besides a number of background and body-image areas, also three $1.3 \mathrm{~cm}^{2}$ bloodstain areas of the observe side of the Shroud were subjected to X-ray fluorescence spectrometry, viz. two areas on the ventral half and one on the dorsal half [8]. In these bloodstain areas the detected iron (Fe) concentration was higher than in the background areas. In the bloodstain in the area of the "pierced" side of the body image, it was even a significant 30 $40 \mathrm{\mu g} \cdot \mathrm{cm}^{-2}$ above background level, while the detected iron level in a stain of whole blood in Whatmann paper was only about $12.5 \mu \mathrm{g} \mathrm{cm}^{-2}$. However, in the Shroud bloodstains no potassium (K) was detected, while the whole blood in Whatmann paper did produce a detectable X-ray fluorescence signal of potassium. Even though microscopic blood samples, e.g. from the reverse of the Shroud, in some but not all cases yielded a small potassium signal in Energy dispersive spectrometry [5] [7] [42]-[44], the X-ray fluorescence spectrometry of the macroscopic bloodstain areas on the observe side of the Shroud shows that the overall potassium level is remarkably reduced in these stains. This lack of potassium in a surplus of iron can be explained by the draining away of the potassium-rich serum from the potassium-poor and iron-rich red blood cells of postmortem blood.

\subsection{Separate Golden-Yellow Serum}

When whole blood is clotting on the skin of a living person, hardly any serum drains from it, as it dries too fast [54]. Recently, it was demonstrated that blood clotting on the skin of a living human body is dry after 15 min and does not make imprints on linen cloth after $30 \mathrm{~min}$ of exposure to air of ca. $24^{\circ} \mathrm{C}$ [55]. Lavoie, Lavoie, Donovan, and Ballas reported that when whole blood is clotting on the relatively cold, unheated surface of non-absorbent plastic, serum readily drains away from the red clot when placed in a vertical position [54]. Recent photos of serum draining away from a blood clot on a glass plate at $18^{\circ} \mathrm{C}-19^{\circ} \mathrm{C}$ are in Figure 9. Also blood 


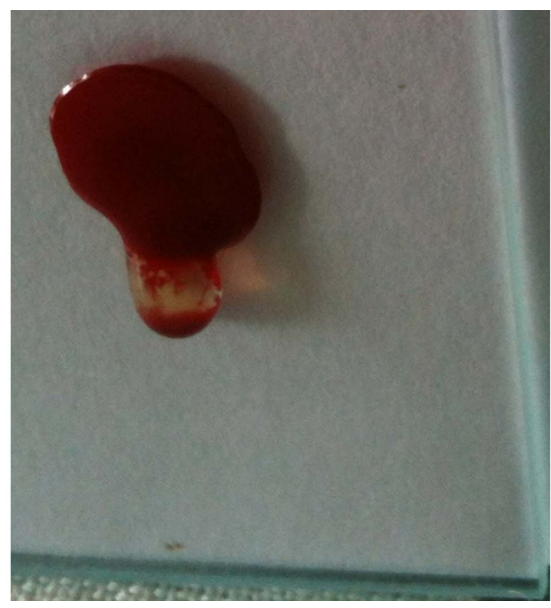

(a)

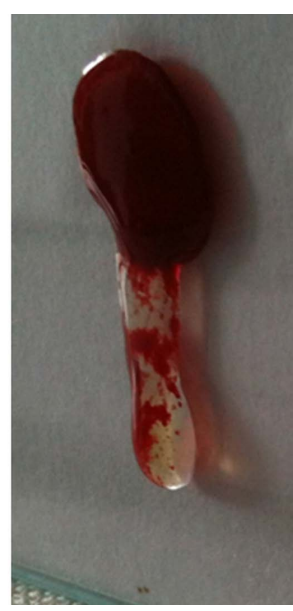

(b)

Figure 9. Serum draining from a human blood clot on a glass plate that was placed from horizontal to vertical $30 \mathrm{~min}$ after the fresh whole blood straight from the finger dripped unto it and was left to clot in a room at $18^{\circ} \mathrm{C}-19^{\circ} \mathrm{C}, 60 \%-70 \%$ relative humidity. (a) clot 40 min old; (b) same clot 60 min old.

clotting on a horizontal relatively cold glass plate forms a ring of exuded serum around the clot, which ring and clot can be imprinted on linen. The fluorescence of this exuded and imprinted serum was photographed with ca. $365 \mathrm{~nm}$ Wood lamp excitation and a UV filter (420 nm cutoff wavelength) in front of the camera, and looks bright yellowish (Figure 10), comparable to the bright yellow-green UV fluorescence in the shape of a halo around the tip of the bloodstain on the wrist image of the Shroud (Figure 4). Fluorescence photography also shows that fresh liquid whole blood fallen on or applied to horizontal or vertical linen cloth does not form fluorescent serum haloes (Figure S16 and Figure S17). Golden-yellow coated microfibers, sampled from Shroud blood areas such as the tip of the wrist bloodstain, were subjected to FT-IR spectrometry [14]. The resulting FT-IR spectra are quite similar to those of human serum albumin [56] — the main constituent of human serum(Figure 11), also numerically [34]. Also the microchemical and immunochemical test results obtained from such Shroud fibers were consistent with the presence of human serum [7] [9] [10]. This separate golden-yellow serum apparently drained and took away the potassium from postmortem blood clotting on a cold surface, such as the skin of a dead person, before the clot and its still wet separate serum margin were imprinted on the Shroud (cf. Figure 12). The bloodstains outside the body image on the dorsal half of the Shroud may have lost their serum and potassium by serum-draining down through the interstices of the tight weave of the starched and therefore cold-water resistant Shroud, acting as a filter while lying on an absorbant bier, e.g., a Jewish bier of bare or cloth-covered wood (Lu 7:14; [57] [58]). Photos of serum draining to the bottom of a narrow plastic container filled with whole blood are in Figure 13. The meandering but neat blood rivulets that flowed across the Shroud in the area of the small of the back [34], can be explained by the rocking of the loaded bier while it was being carried, e.g. by the Jewish 'shoulderers' [58], and while blood was flowing from the relocated and bleeding wrists to the elbows and the small of back of the dead body and then was dripping unto the Shroud.

\subsection{Very Few Red Blood Cells and Survival of Bloodstains}

The draining away of the cold serum would have enhanced the contact between the red blood cells of the postmortem blood and the surface of the Shroud. There, the saponins of yellow madder dye [59] [60] (Figure S9) on the Shroud (Section 4) would have lysed the red blood cells that touched the cloth's surface and would have released their acid content, i.e. the hemolysate. This would have allowed the phenolic madder dyestuffs to denature more of the hemolysate's (met)hemoglobin, and to form stable (pinkish red) complexes with the acid ferric heme, as in the ferric ion test for phenols and in other examples of purpurin and other phenolics binding to iron and heme [25] [61]-[64]. After the drying of the bloodstains and the separation of the body from the cloth and the abrasion of most of the red blood cells and dry hemolysate due to the handling of the cloth in its long history, the pinkish red heme-madder lake would finally be exposed (cf. Figure 12). In a small sticky-tape sample of the 


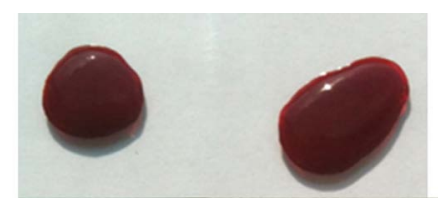

(a)

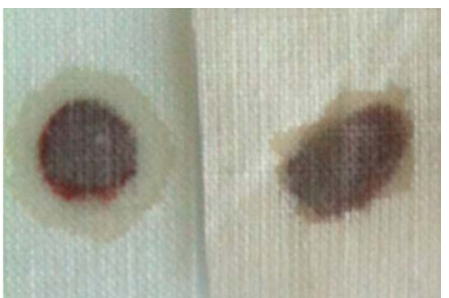

(b)

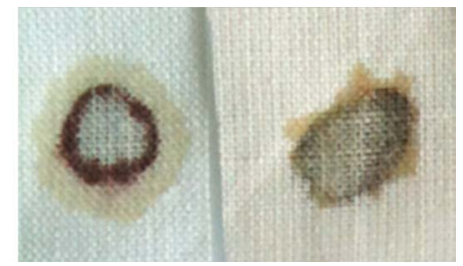

(c)

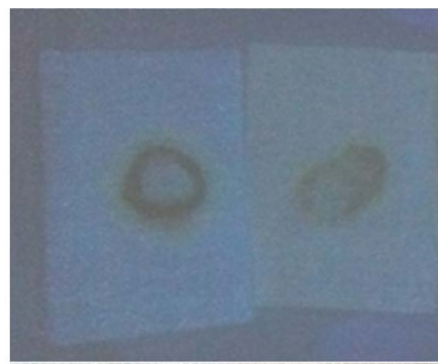

(d)

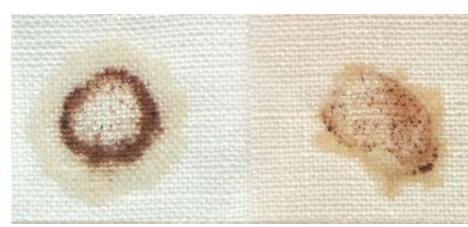

(e)

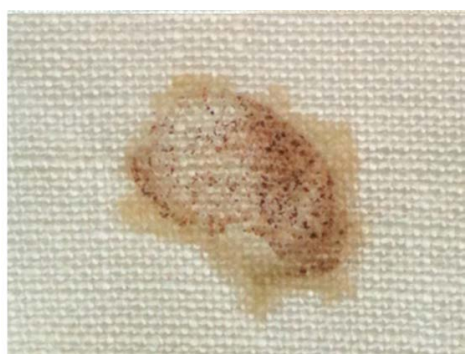

(f)

Figure 10. Imprints in pure (IVN-certified oxygen-bleached) linen and starched + washed + madder-dyed linen of horizontal blood clots formed during 1.5 hour of clotting of the same fresh whole human blood - straight from the finger-in $\sim 23^{\circ} \mathrm{C}, 60 \%$ $70 \%$ relative humidity on a horizontal glass plate. (a) right before imprinting; (b) 7 min after; (c) 17 hours after; (d) 2 days after, under Wood lamp, L-42 UV filter (Hoya) in front of camera, no filter in front of Wood lamp (see blue specular reflection from plate), photo brightness-enhanced; (e) 8 days, contact side, most crusts removed; (f) 8 days, more crusts removed. 


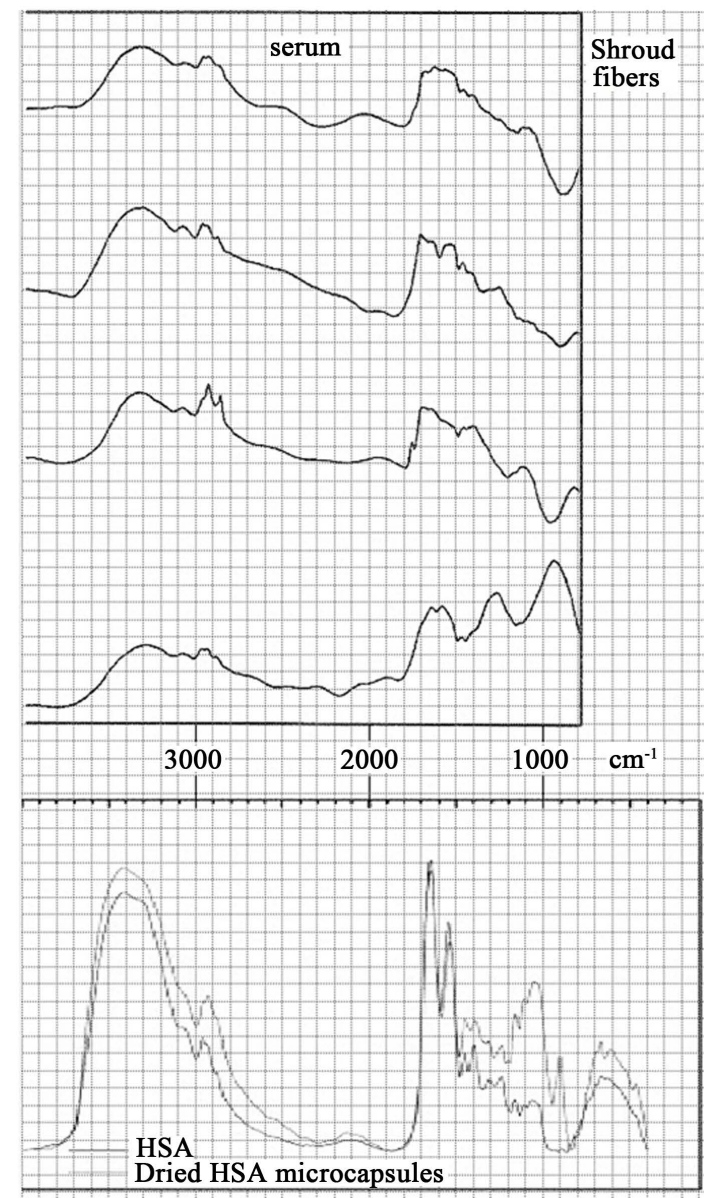

Figure 11. Comparison of aligned FT-IR spectra of Shroud 'serum fibers' (from [14]), and FT-IR spectra of human serum albumin (HSA) (bottom curve: HSA in aqueous solution, top curve: dried HSA microcapsules) (mirrored figure, from [56] CElsevier). Abscissas: wavenumbers in $\mathrm{cm}^{-1}$.

forehead bloodstain (Figure 1), of the first 1500 particles examined by optic and petrographic microscopy, scanning electron microscopy, and X-ray microfluorescence, only 29 were red blood cells [2], and also sticky-tapes from other blood areas showed very few, almost no red blood cells [13] [45]. Madder dye is not colorfast but when it is mordanted red, the mordant has a protecting activity against degradation [22]. For instance, the pinkish red madder lake in an ancient Egyptian painting [65] and in a $6^{\text {th }} \mathrm{c}$. AD manuscript [23] and also some 7 - $9^{\text {th }}$ c. AD red iron-mordanted madder-dyed cloths [66] have survived until today.

\subsection{No Medieval Artwork}

This consistent set of bloodstain data shows that the blood material that caused the bloodstains on the Shroud virtually must have been acid postmortem blood, of which some, before imprinting the serum-rimmed blood stains, had been clotting on a cold surface, such as a the skin of a dead body. Note that some postmortem blood would have flowed from Jesus' dead body as a result of the removal of the nails and the crown of thorns and the handling of the body during the deposition from the cross. Also note that the Gospels say that Jesus' body had already been wrapped in a linen cloth before it was laid in the tomb (Mt 27:58-60 Mk 15:46 Lu 23:53). Nevertheless, there may have been a time interval between the start of the freeing of the body from the cross, with its supposed subsequent deposition on the dorsal half of the cloth, and its being covered with the frontal half of the cloth, during which time interval Nicodemus may have brought his large amount of myrrh and aloes and arranged them beside Jesus on the dorsal half of the cloth (Jn 19:38-42). In this time interval, the newly issued postmortem blood on the front of Jesus' body could have partly dried to serum-rimmed blood clots, like the one 

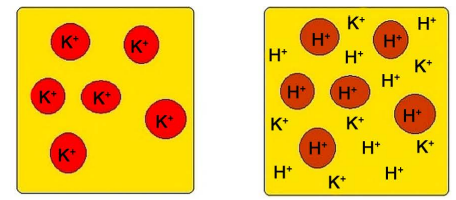

NORMAL DEHYDRATION - ACIDEMIA - DEATH
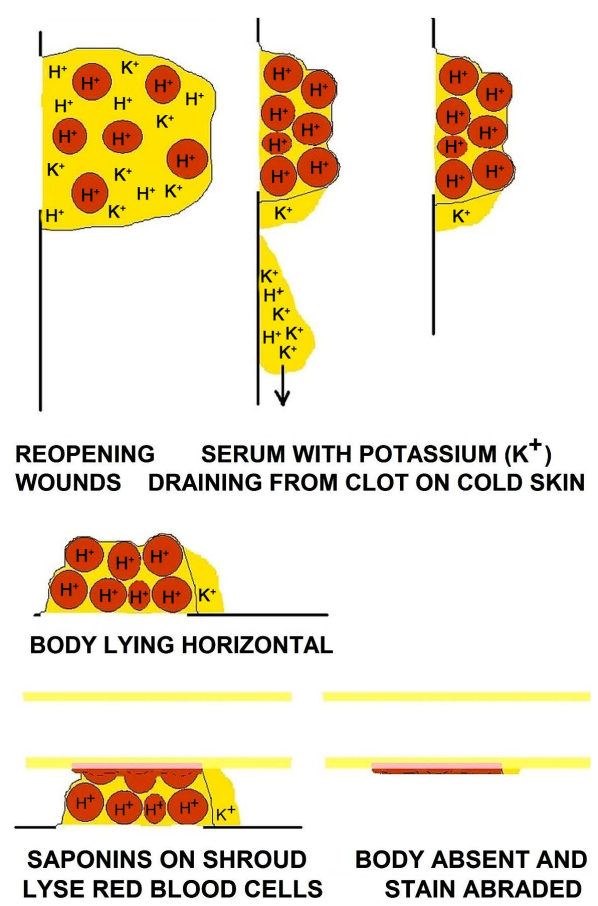

Figure 12. Sketch of hypothesized vertical serum draining and hemolysis and madder lake formation on the Shroud.
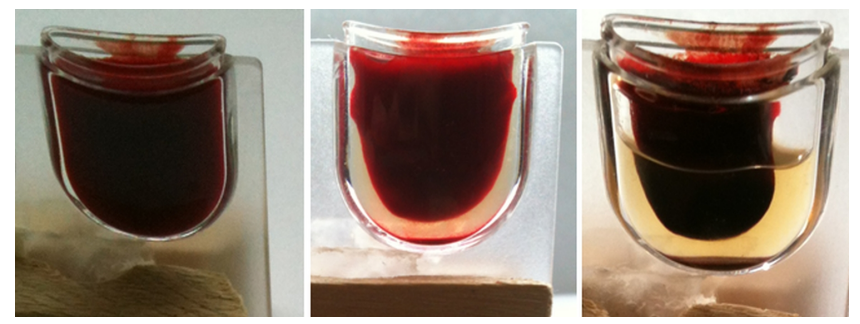

Figure 13. Fresh whole human blood (volume $=1 \mathrm{ml}$ ) straight from the finger separating into serum and red material in a narrow plastic container, right after blood collection, 1.5 hour after, and 16 hours after, respectively.

imprinted on the wrist area of the Shroud. A medieval artist, on the other hand, did not know that serum fluoresces, so he would not have somehow taken acid postmortem blood to let it clot on a cold surface for making imprints on linen.

Another important observation is that, except at the tips of just a few blood-rivulet stains, the color of the Shroud bloodstains are all of the same pinkish red color, whether they are in a body-image area or in a non-image area [11]. Assuming that the bloodstains consist of acid heme-madder lake, both kinds of area must have had a yellow madder-dye coating before the acid postmortem blood got unto the Shroud; however, in bloodless image areas the image fibers do not contain dyes or phenols [7] [9], which is confirmed by the yellow image color that is not altered or extracted by ethanol or methanol—solvents for madder dyestuffs_ [7] [67] [68], and by the assumed oxidative image formation process that would have oxidized the easily oxidizable madder dyestuffs (Sec- 
tion 4.4); so the blood must have got unto the Shroud before the image was formed. A medieval artist most probably would not have been able to imprint or paint the realistic-looking pinkish red bloodstains in the right anatomical locations on the cloth before he or she would somehow produce the still not reproduced body image [69] [70]. Besides, the artist would have to have used an ancient and most probably starched and madder-dyed fine linen cloth for this implausible procedure (Section 4). The medieval-looking result of the radio-carbon-dating of the Shroud, performed on a single sample cut from a corner of the Shroud in 1988, is not an accurate result as the reported radiocarbon ages of the subsamples were statistically shown to be mutually inconsistent and even showed evidence for the presence of a strong linear trend [71]-[74].

\subsection{Hyperfibrinolysis at Postmortem Blood pH below 6.8-Body Not Washed}

The Shroud shows a pattern of many very faint dumbbell-shaped pinkish red bloodstains, compatible with the wounds that would have been caused by an ancient Roman type of scourge [1] [75]. While postmortem blood that had flowed unto intact skin would have been drying, already dry blood clots on scourge wounds that had been inflicted while the person was still alive, may have slowly become moist again, after the person died, in a liquefying process called hyperfibrinolysis. In 1986, a forensic study [76] showed that, in rats, after several kinds of unnatural deaths, the hyperfibrinolysis process starts up at a blood $\mathrm{pH}$ below 6.8 (Figure 14) — a condition met by the blood that stained the Shroud (Section 3.1). The process induces the breaking of the fibrin mesh that binds the red blood cells in a clot that is in contact with the acid plasma. This hyperfibrinolytic plasma remoistens the blood clot and can eventually reliquify it [77]. If scourge wounds had been inflicted less than two days before death, as probably in Jesus' case, the body would not have formed new tissue yet that separated the clots on the wounds from the plasma inside the body [78].

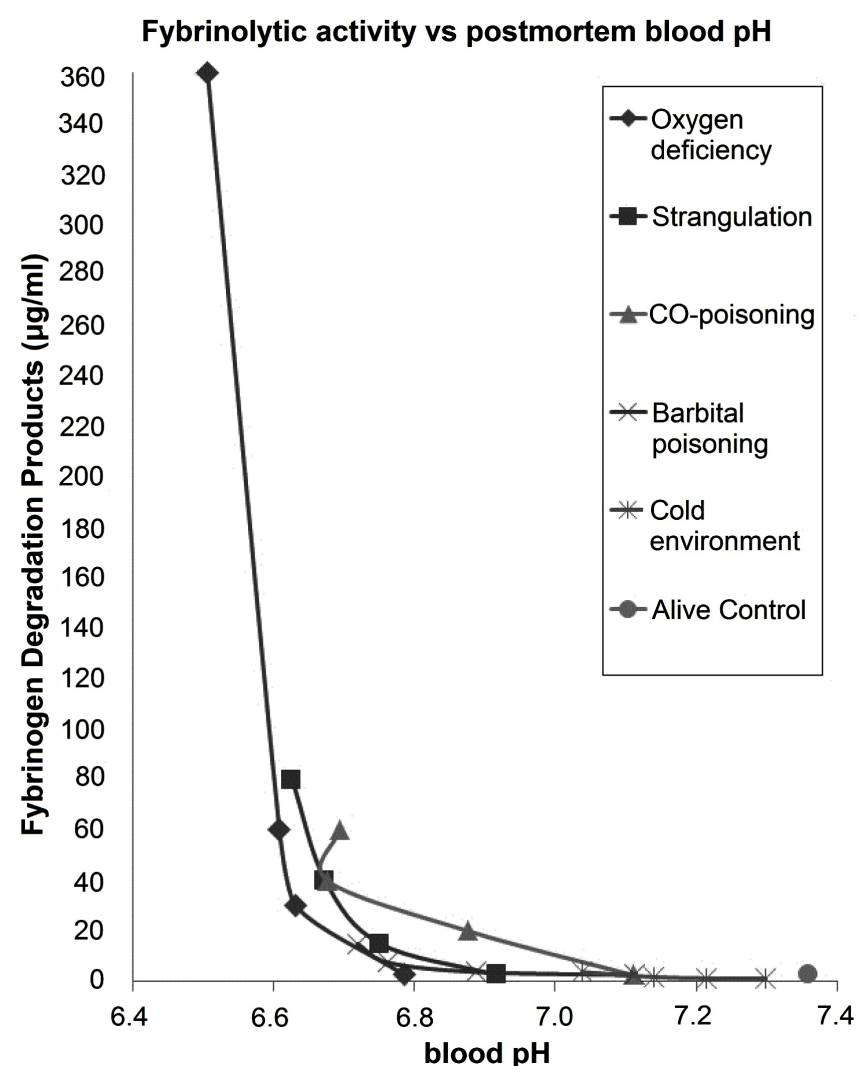

Figure 14. Decreasing blood pH (=increasing acidity), 0, 1, 3, and 8 hours after a sudden death by various causes, versus the increasing concentration of fibrinogen degradation products. Data from a study on rats [76], except the 3-hours values of 'Oxygen deficiency' and 'Cold environment' (these are interpolated from the values of [76]) and the $360 \mu \mathrm{g} / \mathrm{ml}$ value at 8 hours after death by oxygen deficiency (this is the middle of the range given by [76]). 
The blood from Jesus' scourge wounds would have been dry before burial [79]. The body apparently imaged on the Shroud probably was not washed before it would have been placed into the Shroud, as indicated by e.g. the faint bloodstains and the aragonite dirt-having a very good SIMS match to Jerusalem aragonite- found on the Shroud at a knee image (fact A79 of [69]; [80] showing the SIMS spectra of [168]; cf. [81]), and by Zugibe's demonstration [79] that rinsed and soaked, hours-pre-mortem wounds of a corpse do not make imprints and that washing of such wounds (apparently with removal of blood clots) causes an oozing down of blood rivulets, incompatible with the Shroud's faint dorsal scourge bloodstains. However, the pre-mortem acidity of Jesus' blood because of the crucifixion would have corresponded to an earlier and elevated fibrinolytic activity-eventually a hyperfibrinolytic one-before and after death (cf. [82]; cf. [83]), which could at long last have remoistened and acidified the blood clots on the scourge wounds just enough and just in time before evident putrifaction of the body would have set in. Putrifaction sets in ca. 40 hours after death but there are no signs of it on the Shroud [84]. Apparently, body and Shroud separated before prolonged hyperfibrinolysis would have caused larger quantities of blood to seep down from the dorsal wounds. That the dumbbell pattern is still intact and has no apparent smears on both halves of the Shroud and that there are no broken fibers in bloodstains where wet postmortem clots on intact skin would have dried up (facts A72 and A78 of [69]), indicates that the separation of body and Shroud apparently took place in an extremely delicate way.

\section{Shroud Cloth Is Most Probably Starch and Madder Coated}

\subsection{Ultrathin Strippable Surface Layer with Starch}

The linen Shroud cloth, in which, according to textile expert Vial, faults in the preparation of the shafts point to a specifically ancient twill weave manufacturing method [85] [86], is strong and supple and does not readily absorb water [9] [87], even though pure linen cloth easily breaks at creases and is renowned for its rapid absorption of water. During the investigation of the STURP samples, it was learned that surface fibers from various areas of the Shroud-background, light scorch, and image-have an ultrathin (apparently 200 - $600 \mathrm{~nm}$ thick) colored surface layer that is all around these fibers and that can be removed from them by sticky-tape sampling even across linen fiber nodes, as a mold showing the form of the nodes in it [69] [88]. On body-image fibers this layer is straw yellow [89], on non-image fibers it is pale yellow [7], while the cores of both kinds of fibers are colorless [69]. Microchemical tests with iodine and pyrolysis/mass spectrometry (PMS) detected the presence of starch impurities on the surfaces of linen fibers from the Shroud (fact A15 of [69]). An iodine-azide reagent gave a reddish color around fibers from blood areas, and traces of some starch fractions were observed on image fibers [87] [90]. Heller and Adler [7] found no starch or lignin or certain other organic species on main Shroud fibers from sticky-tapes, but emphasized that positive tests in some cases would have been more meaningful than the negative tests. Perhaps they counted only a blue-black color with iodine as a positive test for starch, for they wrote that the specimens were "tested by standard microchemical techniques", and-although they gave a mistaken reference for their "iodine-iodide" test for starch-the positive result for this standard starch test is blue-black (p. 38, 54 of [7]; e.g. [91] [92]). Furthermore, on threads and superficial fibers from the corner that was radiocarbon-dated, a coating of starch-also here giving a red color with iodine-plus a yellow dye like madder was found; the cores of the threads were nearly colorless [87] [93] [94].

\subsection{Radiocarbon-Dating Corner with Retrograded Starch and Madder Dye Is Not a Repair}

The arguments for a $16^{\text {th }}$ century repair in the radiocarbon-dating corner [95]-[100], and for any repair there from another era, can all be refuted, and there is strong evidence that disproves a repair (Table 1). Originally, the Shroud probably was an extremely fine first-century Jewish priest's temple mantle (Mishnah, Middot 5:4)with Pharisaic enlarged border (Mt 23:5 KJ21)—which was not allowed to be washed or be worn-out [101], and thus could have a uniform dye on top of a washable starch coating [102] [103]. For its manufacture, an acid cooked starch paste, as mentioned by Pliny the Elder [104] [105], probably was wiped on the surface of the threads as a lubricant during the weaving of the linen. After the weaving of the cloth and the retrogradation of the starch, most of this starch would have been washed off, with moderate-temperature re-gelatinisation and retrogradation, making the lower molecular weight fractions, like single-helical amylose which gives a blue color with iodine, leach out of the starch, and leaving a film of the higher molecular weight fractions of retrograded starch-double-helical aggregates of amylose and amylopectin which give a red color with iodine-intact around 
Table 1. Evidence against a corner repair (descriptions in [34] and [103]).

\begin{tabular}{|c|c|c|}
\hline \multirow{2}{*}{$\begin{array}{l}\text { Both radiocarbon-dating corner and main } \\
\text { Shroud show evidence for }\end{array}$} & \multicolumn{2}{|r|}{ References } \\
\hline & References corner & References main Shroud \\
\hline (retrograded) starch & [87] [93] [94] [96] & fact A15 of [69]; [87] [88] [90] [141] \\
\hline cotton fibers & [87] [141] [153] & [93]; appendix of [153] \\
\hline flaked yellow carbohydrate coating in scorch areas & [87] [99] [141] & [130]; fig. VII-3 of [141]; [154] [155] \\
\hline anomalous yellow-green fluorescence & [4] & {$[15][27]$} \\
\hline $\begin{array}{l}\text { occasional rose madder (aluminum lake) particles } \\
\text { stuck to non-image fibers while wet (probably from } \\
\text { airborne dust that got stuck to and mordanted the drying dye) }\end{array}$ & [87] [99] & [156]-[159] \\
\hline $\begin{array}{l}\text { pentoses or furfural (from scorched hemicellulose) } \\
\text { in scorch (not in not-scorch) }\end{array}$ & [141] [160]; cf. [122] & [141]; cf. [122] \\
\hline $\begin{array}{l}\text { no Arabic gum, for no proteins or denatured proteins } \\
\text { detected; gum in corner can be scorched starch = starch gum }\end{array}$ & [87] [89] [161] & [88] [162] \\
\hline $\begin{array}{l}\text { same relative concentrations of calcium, strontium and iron, } \\
\text { probably from the retting of the flax stems }\end{array}$ & [45] on main Shroud a & 1973 Raes threads results; [150] [151] \\
\hline pectins & & [89] \\
\hline aluminum in waterstains & & [152] \\
\hline $\begin{array}{l}\text { continuous radiographic bands in large corner area, } \\
\text { also through the side seam into the side strip }\end{array}$ & {$[151$} & 52], Figure 7 of [45] \\
\hline $\begin{array}{l}\text { transmitted light photo showing continuous bands } \\
\text { (also through side seam) "disproves the hypothesis that the } \\
\text { Shroud was rewoven in that area" ([163] p. 9) }\end{array}$ & & ; Figure 6 of [163] \\
\hline similar PMS spectra & [122] & scribed in Section 4.6 \\
\hline $\begin{array}{l}\text { similar FT-IR spectra. Radiocarbon FT-IR } \\
\text { "shows physical characteristics of both the waterstain } \\
\text { and scorch regions of the cloth.” ([14] p. 98) }\end{array}$ & & 16]; cf. Section 4.6 \\
\hline $\begin{array}{l}\text { radiocarbon sample is in midst of scorch mark } \\
\text { and at edge of pre-1532 waterstain }\end{array}$ & & 5] [97] [110] [160] \\
\hline $\begin{array}{l}\text { threads of Raes and radiocarbon corner have } \\
\text { loom-indentations due to having been woven on a loom, } \\
\text { so not inserted by thread-by-thread 'French weaving' }\end{array}$ & & [98] [153] \\
\hline $\begin{array}{l}\text { no shown vanillin difference. "No samples from any } \\
\text { location on the Shroud gave the vanillin test." ([141] p. 43) }\end{array}$ & & [122] [141] [164] \\
\hline $\begin{array}{l}\text { no developed color difference } \\
\text { between Shroud and dyed assumed 'patch' }\end{array}$ & & [1] [160] \\
\hline $\begin{array}{l}\text { not the slightest hint of a mending operation, a patch or some } \\
\text { kind of reinforcing darning on whole Shroud, front and reverse }\end{array}$ & Textile expert and S & ud conservator Flury-Lemberg [123] \\
\hline $\begin{array}{l}\text { apparently the same stitching of the hem (hem rolled across the } \\
\text { seam) and the same unusual (first-century Jewish type of) } \\
\text { stitching of seam (2 lines of overhand sinusoidal sewing) }\end{array}$ & & [123] [165] \\
\hline $\begin{array}{l}\text { no black straight sewing thread of patch in } \mathrm{X} \text {-ray, } \\
\text { for there is no opaque black material in } \mathrm{X} \text {-ray }\end{array}$ & & [97] \\
\hline $\begin{array}{l}\text { no vertical seam of stitched-in patch } \\
\text { but continuous float and weft threads }\end{array}$ & & [95] [97] \\
\hline $\begin{array}{l}\text { 2-ply S-twist sewing thread of side-seam } \\
\text { complies with 1-ply Z-twist of weave }\end{array}$ & & [97] \\
\hline $\begin{array}{l}\text { Raes thread \#1 no 'spliced' thread but thread only } \\
\text { partly dyed/dirtied because other part was protected } \\
\text { inside hem or seam; its thread ends are chemically similar } \\
\text { and with unexpected silicon throughout length of thread }\end{array}$ & {$[17][$} & ]; cf. Figure 3 of [163] \\
\hline $\begin{array}{l}\text { the greasy dirt on the corner } \\
\text { can explain different color in 'UV-photo' }\end{array}$ & & [100] [123] \\
\hline $\begin{array}{l}\text { all bottom corners of the Quad Mosaic images } \\
\text { of the Shroud are green, also where the Shroud } \\
\text { has no corner, apparently due to not-uniform illumination }\end{array}$ & & [97] [167] \\
\hline
\end{tabular}


the surface fibers ([87] [106]; cf. [107] [108]). The starch probably was not washed off completely deliberately because it would be a dirt repellent and fabric strengthener and lustrous finish, especially after polishing the cloth with a glass ball or slick stone. After washing, the cloth probably was dyed with an acidic madder root extract to give a more uniform color to the unevenly colored batches of linen that gave the cloth a banded appearance, undesirable for a fine mantle. Now that most madder dye probably has degraded, differently colored warp and weft bands are clearly visible on the lustrous Shroud (facts A21 and B14 of [69]).

\subsection{Reflectance of Shroud Background}

The UV-vis raw reflectance scan of a background area of the Shroud looks quite irregular (Figure S18) [12]. In the average spectrum (referred to magnesium oxide) of five background areas (Figure S19) no $450 \mathrm{~nm}$ band of yellow madder dye is discernible [12]. However, the discernment of a reflectance band of yellow dye can be impossible due to ageing of a yellow-dyed cloth [109]. Nevertheless, the fact that Pellicori [19], by artificial ageing (=baking), could not simultaneously give a pure linen cloth the same color and the same darkness as the Shroud (Figure S20), may be an indication for the presence of a remnant of yellow madder dye on the Shroud.

\subsection{UV Fluorescence Photography of the Shroud}

The UV fluorescence of the Shroud background is yellow green [27], and this fluorescence is not typical of other known old linen cloths [15]. Clear evidence for the presence of a fluorescent coating on the whole Shroud is visible in its UV fluorescence photos [27]. After the Shroud had been partly burnt and scorched during the church fire in Chambery of $1532 \mathrm{AD}$, dousing water made water stains in the same symmetry pattern as the burn holes and scorch marks. The insides of some of these water stains-both on the frontal and dorsal half of the Shroud, mostly outside the body image — are lighter than the background in the ordinary light photos, but darker and bluer in the UV fluorescence photos (Figure 15). This phenomenon is not seen in the water stains of the
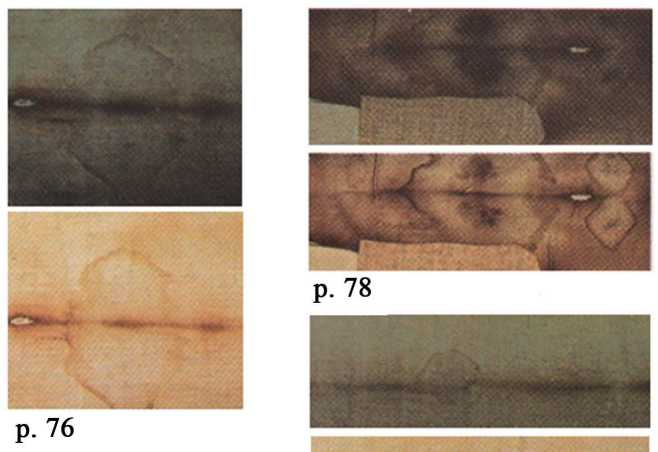

$$
\text { p. } 78
$$

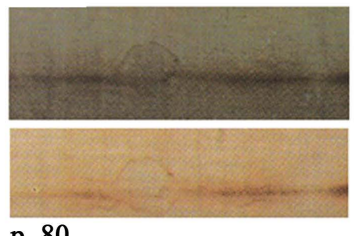

p. 80
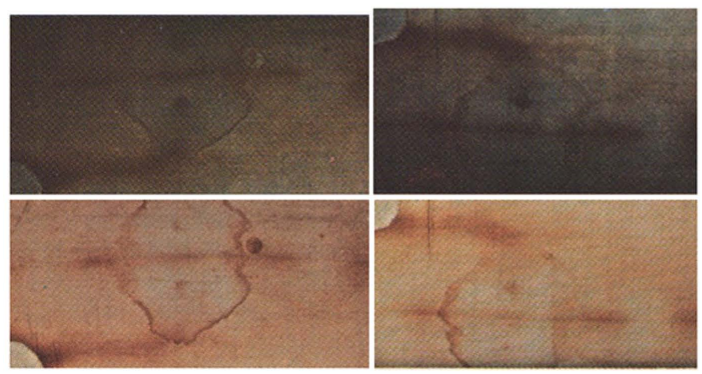

p. 83
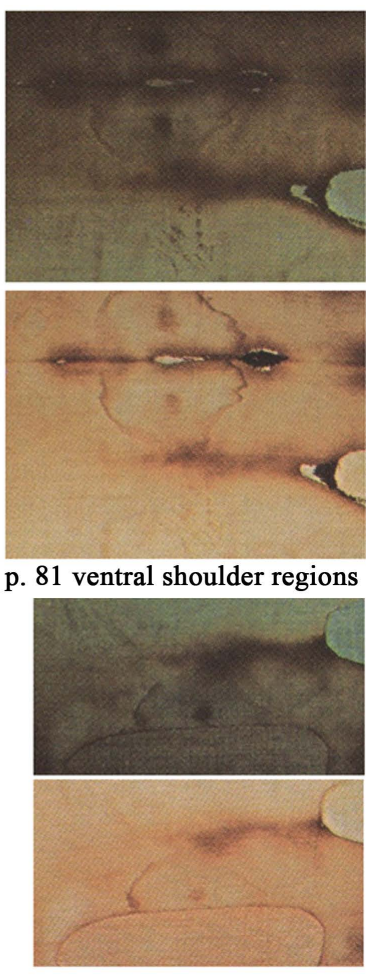

Figure 15. UV-fluorescence photos of the Shroud at $1532 \mathrm{AD}$ water stains (cropped from figures of [27]). P. 76: at the height of the dorsal calves, p. 78: at the height of the dorsal shoulders, p. 80: at the height of the dorsal top of the head, p. 81: at the height of the ventral shoulders, p. 83: at the height of the ventral knees. From [27] with permission from the Biocommunications Association, Inc. (C)1981 Biocommunications Association, Inc. 
other type, viz. the large diamond-shape water stains in another symmetry pattern, which are assumed to have been caused before 1532 by cold water [110]. Experiments show that pieces of oxygen-bleached linen that were coated with acid starch paste and dyed yellow with various types of acidic madder root extract, can take several different colors in UV fluorescence photography (Figure S21), also a color comparable to that of the Shroud's UV fluorescence (cf. Figure 4 and Figure S11). As retrograded starch is insoluble in cold water but soluble in hot water, it is very plausible that the Shroud's dousing water locally washed away the coating of starch and madder, where the cloth was still hot and/or the dousing water had become hot in the 1532 fire. Furthermore, STURP reported that the Shroud's body-image - only constituted by a uniform straw yellow color of the whole circumference of the ultrathin strippable layer of superficial fibers in the image areas [69] —is less fluorescent than the background, and that, in a few blueish fluorescent weave areas of the Shroud, the body-image is much less dense than expected, as if these particular weave areas were 'no-print' areas [12] [27]. These findings suggest that the body-image formation process, which according to Heller and Adler is best described as a dehydrating acid oxidation process [7] [9] [111], degraded a fluorescent coating more easily than the actual linen. Madder's main dyestuffs alizarin and purpurin are indeed easily oxidizable — they can even be explosive — [68] [112] [113] and would have been yellow and thus acid dyestuffs on a probably acid starch coating on the Shroud. Also, these hydroxy-anthraquinones would probably have lost fluorescence intensity if, during image formation, less (or more) benzene rings got fused in the straight chain than their original three and also if they lost their hydroxyl groups and thus would no longer be phenolics [114]. There are no phenolics or dyes on Shroud image fibers (Section 3.5).

\subsection{UV Fluorescence Spectra of Shroud Background}

The UV fluorescence spectra of the Shroud were measured with $365 \mathrm{~nm}$ excitation, and a typical raw fluorescence scan of a $6 \mathrm{~mm} \times 3 \mathrm{~mm}$ background area (Figure 16) shows beside the broad $435 \mathrm{~nm}$ band of probably lignin [32] also a shoulder at 510 - $540 \mathrm{~nm}$. This shoulder can be attributed to acid yellow madder dye, as this dye contains a variable ratio of alizarin and purpurin, of which the acid, protonated forms fluoresce near 500 and $575 \mathrm{~nm}$, respectively [24].

\subsection{FT-IR and PMS Spectra of Main Shroud and Radiocarbon-Dating Corner}

Four kinds of samples from the Shroud's radiocarbon-dating corner were subjected to FT-IR analysis: 1) threads and a crust from a thread from the so-called 'Raes sample', i.e., the small triangle that in 1973 was cut from the very tip of a corner, 2) threads from the larger 'Radiocarbon'/'Riserva' rectangle that was cut from the same corner in 1988 for radiocarbon dating (the 'Riserva' was retained in Turin, while the actual 'Radiocarbon' sample was examined by radiocarbon-dating labs) 3) fibers (later called 'Riggi' fibers) from a small piece of linen fabric from the Shroud right beside the area of the 'Riserva' [115] 4) fibers from a corner, either 'Riggi' fibers or fibers vacuumed from the reverse of a larger area around the radiocarbon-dating corner [116], for no stickytape samples were taken from the corners in 1978 or 1988 (Figure 17).

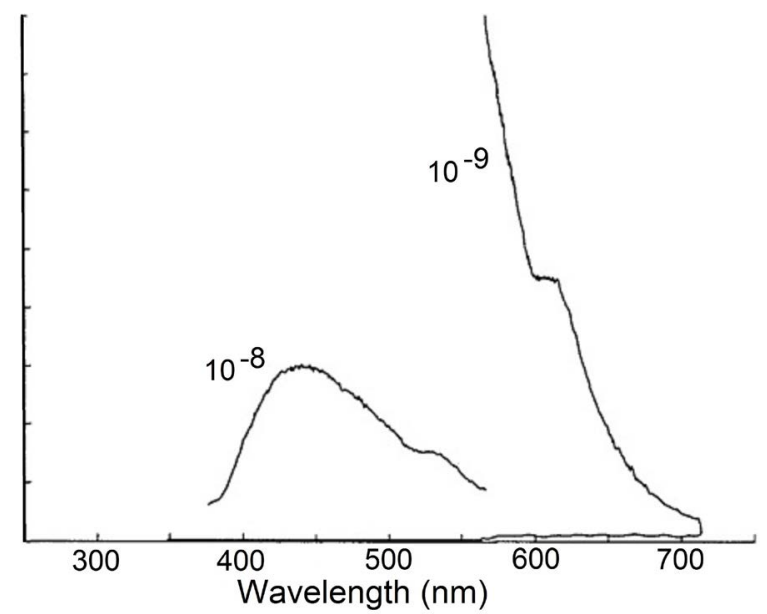

Figure 16. Typical raw fluorescence scan of the Shroud background. From [12]. 


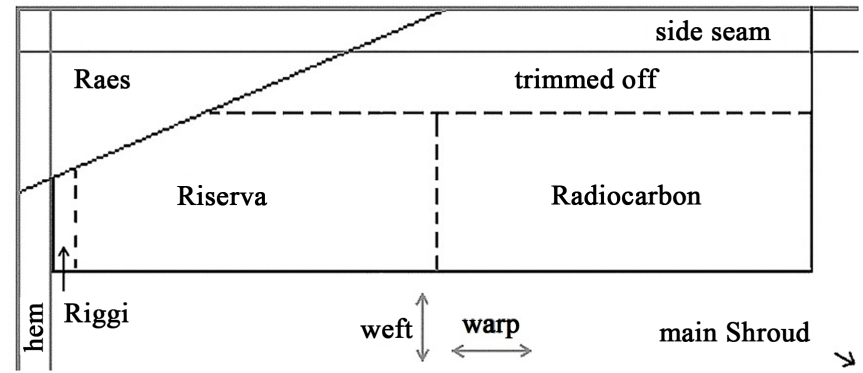

(a)

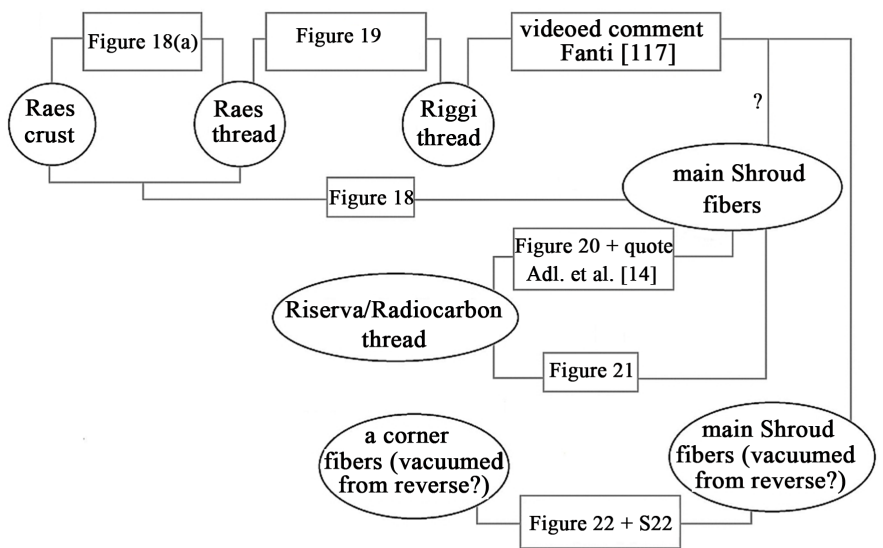

(b)

Figure 17. (a) Schematic sketch of the sample areas of a corner of the Shroud; (b) Configuration of comparable FT-IR spectra in this paper. The location of the 'Riggi' piece was deduced from G. Fanti's statements that it is "the border of the Riserva" and that a $8-9^{\text {th }}$ c. AD radiocarbon-date of the piece would confirm the linear trend indicated by the reported radiocarbon-ages of the 1988 subsamples ([117] 14:00 to 19:53). Also, the piece contained a $12 \mathrm{~mm}$-long weft thread (cf. [153] appendix and [154]), and the hem was not trimmed off (cf. [163]). Alas, G. Fanti was forced to be silent to some of my questions.

FT-IR spectra of a yellow-brown circular cocoon-shaped crust and the tight yellow-coated end of Raes thread \#1 are very similar (Figure 17(b) and Figure 18(a)) and their ca. $1600 \mathrm{~cm}^{-1}$ peak is much more prominent in the crust. A part of an FT-IR spectrum of the 'Riggi' fibers, showing only the 4000 to $1300 \mathrm{~cm}^{-1}$ wavenumber region, is similar to an FT-IR spectrum of Raes thread \#14, and both show the ca. $1600 \mathrm{~cm}^{-1}$ peak (Figure 19). Fanti said that the "fingerprint results" of some 'Riggi' fibers were "the same" as those of main Shroud 'nonimage’ FT-IR spectra ([117] at 16:25-17:50). Some typical FT-IR spectra of fibers from a thread of the 1988 'Radiocarbon'/‘Riserva' rectangle and from various areas of the main Shroud show that the 'radiocarbon' and 'non-image' spectra are similar (Figure 20). According to Adler, Selzer, and DeBlase [14], the “radiocarbon” spectra have a peak at $1590 \mathrm{~cm}^{-1}$ and the 'non-image' spectra have one at $1593 \mathrm{~cm}^{-1}$. Another comparison, including a detailed wavenumber comparison [34], of more of the spectra of Adler, Selzer, and DeBlase [14] showed that their 'radiocarbon' FT-IR spectra are indeed similar to their main Shroud's 'non-image' spectra (Figure 21). The same holds for the FT-IR spectra of the Raes corner samples (Figure 18).

Here must be noted that the FT-IR-examined Raes threads, especially the yellow end of Raes thread \#1, had a colored coating which was on all Raes threads and which contained starch, a gum-probably starch gum from starch that got roasted during the 1532 AD fire, cf. Table 1 -and a yellow dye showing the same acidichromism as madder dye [87] (cf. Figure S9). A comparison of the peak wavenumbers of the FT-IR spectra of the Shroud with those of online reference FT-IR spectra of linen (new and old), starch, and madder, shows that the Shroud's 'non-image', 'radiocarbon', and 'Raes' FT-IR spectra are not only compatible with the presence of these components but even seem to need the presence of the aromatic madder dyestuffs to explain all peaks, especially the $1600 \mathrm{~cm}^{-1}$ peak [34], which is not present in FT-IR spectra of ancient linen from a mummy and of ancient linen from the Dead Sea area [118], or in those of several linen cloths from 3500 BC to 1800 AD [119]. In 2015, seven more FT-IR spectra of non-image fibers from a corner and from the hands- and gluteal-image areas of the 


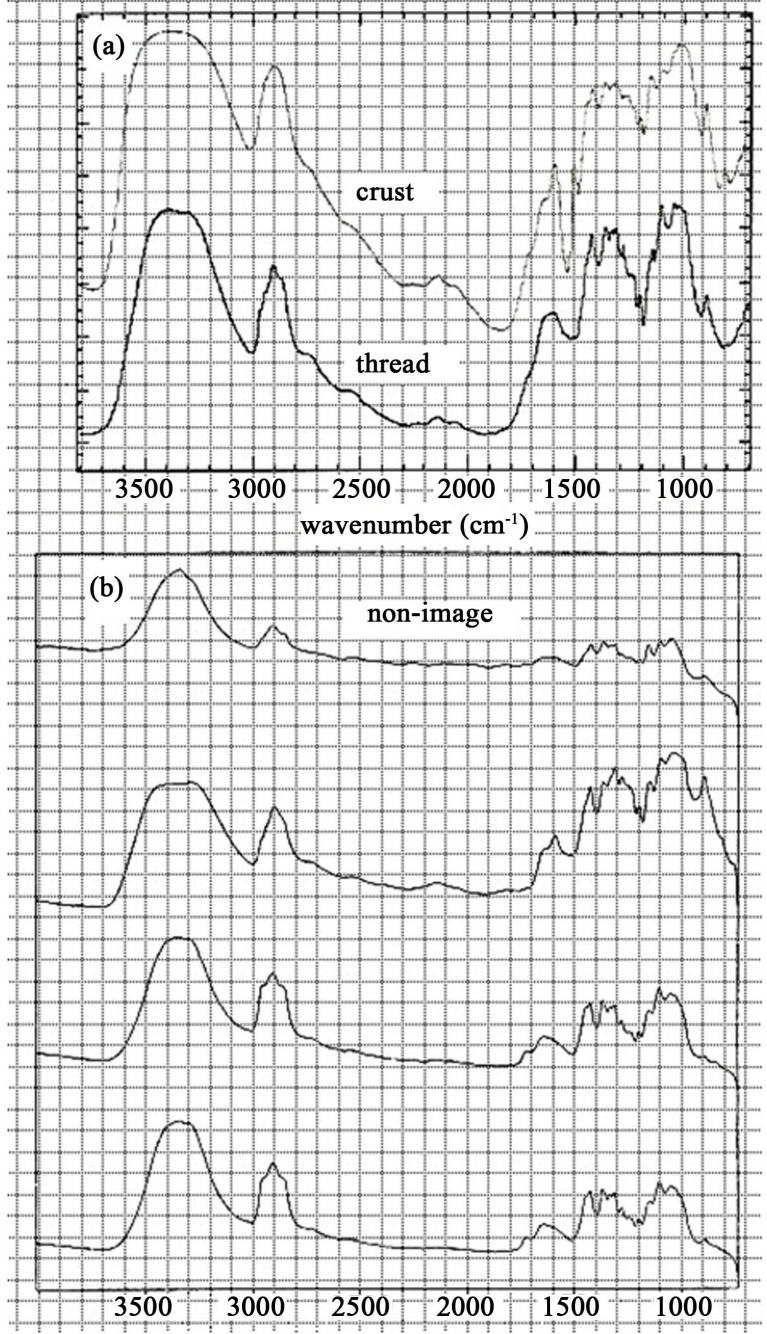

Figure 18. Comparison (with added lath) of (a) FT-IR spectra of a large piece of the yellowbrown crust (upper curve) and the yellow-coated thin end (bottom curve) of Raes thread \#1 (from [17] (C)2009 Edizioni Libreria Progetto) to (b) the FT-IR spectra of main Shroud non-image fibers (from [14]). Abscissas: wavenumbers in $\mathrm{cm}^{-1}$.

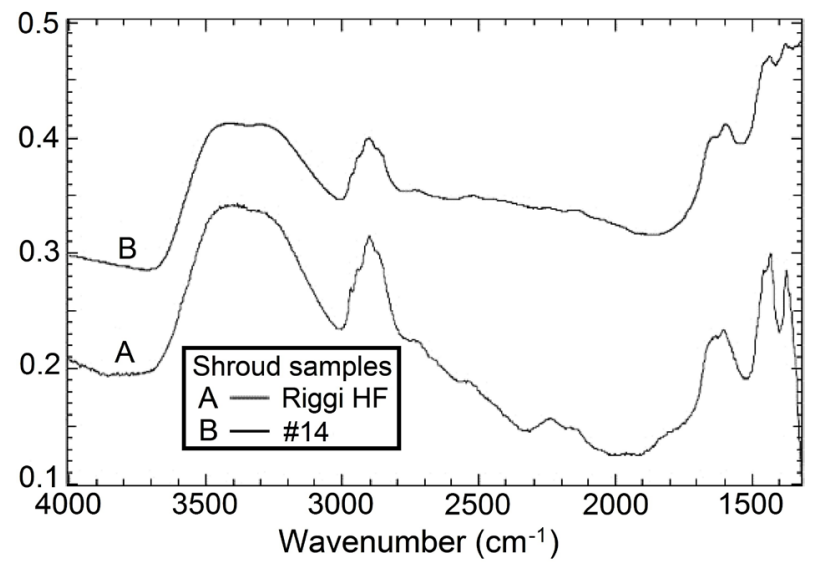

Figure 19. FT-IR spectra of (A) the 'Riggi' fibers from a piece of fabric right beside the 'Riserva' of the 1988 sample and of (B) Raes thread \#14. From [118]. 


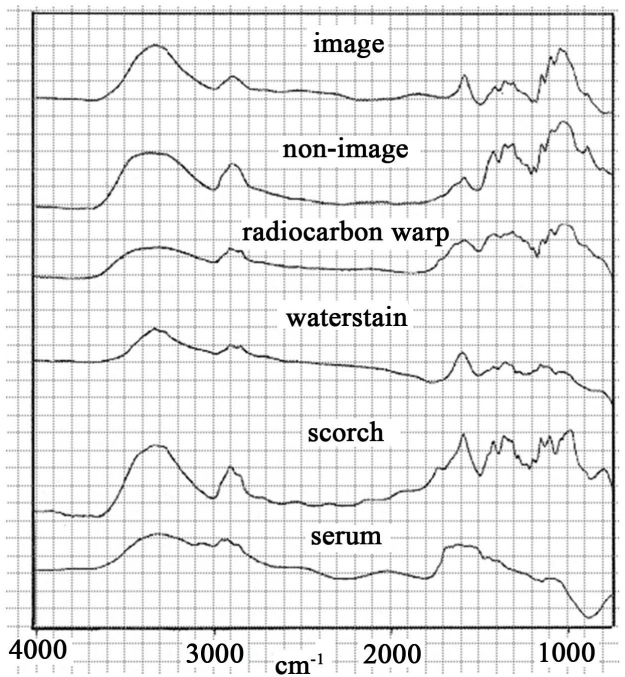

Figure 20. Typical FT-IR spectra of various Shroud fiber samples, covered with lath. From [16] (C)American Chemical Society. Abscissa: wavenumbers in $\mathrm{cm}^{-1}$.

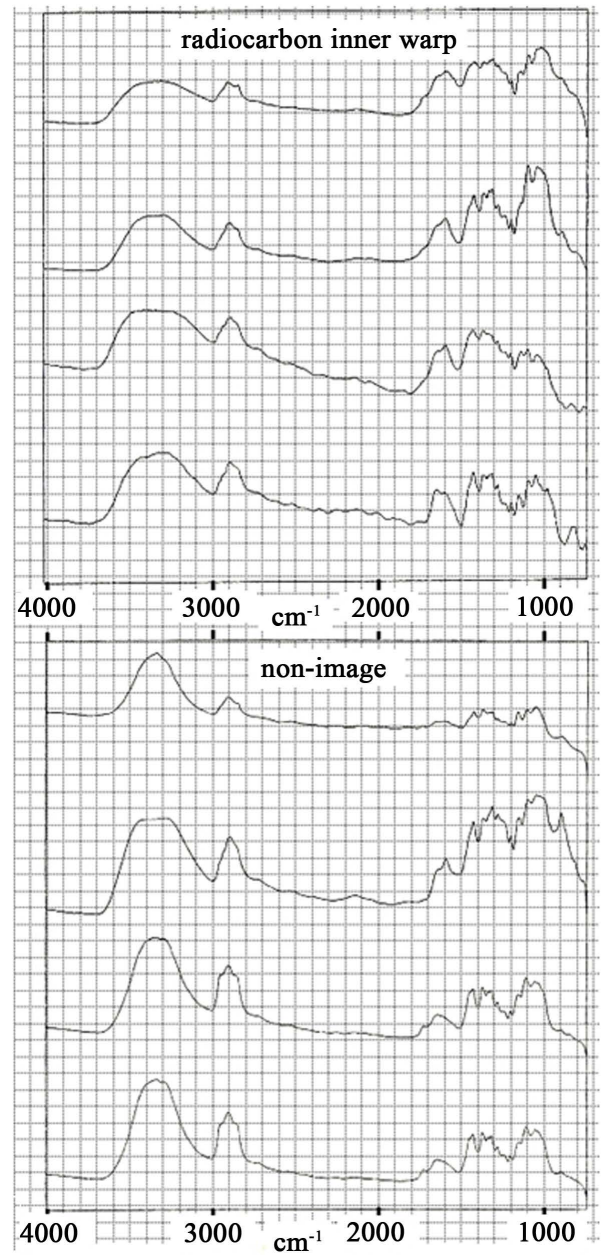

Figure 21. Comparison of aligned plots of FT-IR spectra of fibers from an inner warp thread of the radiocarbon-dating sample and of main Shroud non-image fibers. From [14]. Abscissas: wavenumbers in $\mathrm{cm}^{-1}$. 
(main) Shroud were published [120]; these main Shroud fibers were probably vacuumed from the reverse of the Shroud, for the hands and gluteal areas were indeed vacuumed [116], and STURP's tape samples are identified by a code, e.g. STURP-1EB, in the same 2015 publication, and no STURP-tapes were taken from the gluteal area [121]. All four main Shroud spectra plus one 'corner' spectrum very clearly show the ca. $1600 \mathrm{~cm}^{-1}$ peak (Figure 22 and Figure S22(a)), and seem compatible with the previously published 'non-image' and 'radiocarbon' FT-IR spectra of the Shroud.

Recently, Bella, Garlaschelli, and Samperi [122] reported that there is no significant difference between two earlier published PMS spectra [99], viz. of an image fiber from the main Shroud and-a partial spectrum not showing the base peak - of fibers from the Raes sample, respectively, after subtraction of the fragmentation pattern (a cluster of 14-mass-units-spaced peaks) of an aliphatic hydrocarbon-derived contamination from the latter. This contamination probably consists of the greasy handling dirt observed on the corners of the Shroud [123], for e.g. palmitoleic acid, a major fatty acid (group) in human sebum (16:1 $\Delta 9)$, has a mass spectrum that is quite similar to the reported (possibly partial) contamination pattern [124] (cf. [125]).

\subsection{Not a Saponaria Soap Residue or a Bioplastic Coating or Oils}

The high solubility, brown-to-colorless acidichromism, blue color with iodine, and yellow lake color with $\mathrm{Al}^{3+}$ and $\mathrm{Ca}^{2+}$ of a Saponaria soap residue preclude that the presence of such a residue on the Shroud-hypothesized by Rogers and Arnoldi [87] — is the cause of the pinkish-red color of the Shroud bloodstains; the low solubility, yellow-to-red-to-blue acidichromism, lack of color with iodine, and red and blue lake color with $\mathrm{Al}^{3+}$ and $\mathrm{Ca}^{2+}$, respectively, of yellow madder dye, on the other hand, fit the corresponding Shroud data very well (all respective references are in [34]).

Garza-Valdes [4] hypothesized that the Shroud has a thin bioplastic coating produced by microorganisms. However, the proteins, sulfur compounds and photosynthetic pigments of such a coating were not detected on the Shroud by wet chemistry and PMS [87] [88].

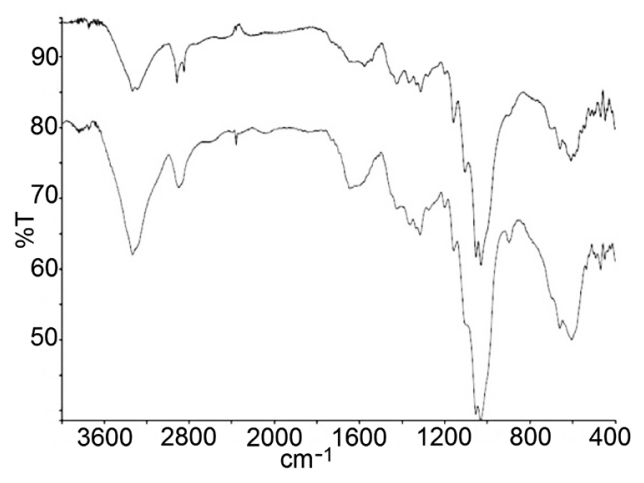

(a)

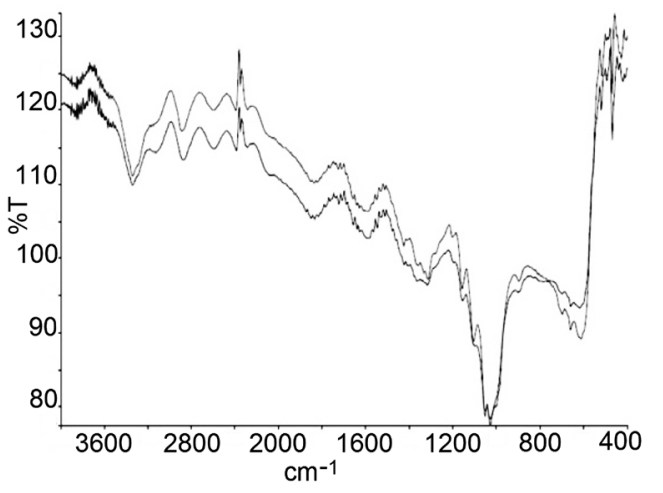

(b)

Figure 22. FT-IR ATR spectra of non-image fibers from (a) a Shroud corner and (b) the Shroud's gluteal-image area. From [120]. Abscissas: wavenumbers in $\mathrm{cm}^{-1}$. 
That only oils constitute the Shroud's strippable layer, is improbable, for oil is not soluble in hot water, so it would not have been removed in the hot-water stains, nor would it be strippable from linen fibers as molds showing the forms of linen fiber nodes. When oils or waxes are present on a linen cloth, its FT-IR spectrum shows sharp peaks at ca. $2925 \mathrm{~cm}^{-1}$ and $2850 \mathrm{~cm}^{-1}$ (cf. Figure S23) [126] [127], but such peaks are not present in the FT-IR spectra of fibers from the main Shroud that were probably vacuumed from the reverse (Section 4.6) (Figure 22(b), cf. Figure S22(a)). The presence of such peaks in the top FT-IR spectrum of Figure 22(a) of a (vacuumed-off/cut-off) corner fiber, may be due to the greasy handling dirt observed on the corners of the Shroud [123], just as the PMS-contamination pattern found there. When present on linen, perspiration plus skin oils, olive oil, and myrrh tincture are stable to the temperatures associated with proximate scorches [19], and heating olive oil to $185^{\circ} \mathrm{C}$ for 4 or 8 hours does not induce a position shift or a major intensity change of its 2925 and $2854 \mathrm{~cm}^{-1}$ aliphatic- $\mathrm{CH}_{2}$ peaks in FT-IR [128]. So, it is unlikely that such oils, if originally present on the main Shroud, would have become undetectable due to the 1532 AD fire. Although particles of myrrh and aloes were identified, some stuck to fibers, on Shroud samples by optical microscopy [129] [130] and by immunofluorescence, this last technique obtained a totally negative response for myrrh and for aloes from fibers (without particles) from a cut main-Shroud thread [131]. Neither myrrh nor aloes stains on linen cloth fluoresced under the excitation used for the Shroud's fluorescence spectroscopy, an olive oil stain fluoresced a faint reddish gray color, and a perspiration plus skin oil stain fluoresced yellow; there was no fluorescence color or brightness difference between scorched and (adjacent) unscorched areas of these stains [19]. Therefore, these substances cannot account for the anomalous fluorescence of the Shroud's background and hot-water stains. Besides, blood stains on linen soaked with myrrh, olive or sesame oil turn brown (Figure S24).

\subsection{Not Just the Primary Cell Wall of Linen Fiber}

The hypothesis that the strippable layer on the Shroud's surface fibers is just a linen fiber's primary cell wall (PCW) [132] was not presented with positive evidence: the width of a dark line at a border of the layer seen in light microscopy was measured $(0.2 \pm 0.2 \mu \mathrm{m})$, but the width of this line may not be the thickness of the layer, because the layer need not have been seen perpendicular to the focal plane. Besides, the thickness of a pure linen fiber's PCW was not measured or cited, and it was not demonstrated that the PCW can be stripped from a linen fiber-even continuously across linen fiber nodes - by a sticky-tape. The presented arguments against a starch coating - i.e., that an evaporation residue of a starch 'solution' would not be all around the surface fibers (which seems correct) and that no references to the use of starch in antiquity were found-are countered in Section 4.2, above. Besides, the PCW of a linen fiber is not soluble in boiling water [133] and thus would not have been removed in the Shroud's 1532 hot-water stains. Pectins, constituting the boiling-water-soluble 'glue' between neighboring PCW's in a flax stem, are not fluorescent, for they have to be made fluorescent by labelling [134], so they cannot account for the anomalous fluorescence of the Shroud's hot-water stains or background either.

\subsection{Preservative Madder Dye Washed off by Toluene and Xylene}

The collective of data from the Shroud background areas allows the conclusion that the whole Shroud has an ultrathin hot-water soluble and strippable coating that most probably consists of retrograded starch and acid yellow madder dye. This coating would have functioned as a dirt-repellent and sealing fabric strengthener and brightener for the fine linen mantle, a water-resistant filter for the whole blood, a hemolysing saponin layer for the red blood cells, a substrate for heme adsorption and pinkish red lake formation, an acid substrate for acid oxidation in the probably oxidative image formation process, and finally a strong preservative for the Shroud's conservation throughout its long history. Madder dye is antimicrobial, antifungal, and insecticidal [135]-[140]. That Shroud fibers from sticky-tape samples were flushed with xylene and toluene-solvents for madder's main dyestuffs alizarin and purpurin [67] [68] [113]— to free them from the sticky-tape's adhesive before they were subjected to STURP's microchemical spot tests [7] [9] [87] [141], may explain why no madder dye or any other phenolic was reported as present on the Shroud. Xylene is not a solvent for a bioplastic coating [88], but, like toluene, is a solvent for oils.

\subsection{Not Madder on Top of Bloodstains on Pure Linen}

If blood got unto a pure linen cloth, there would be no water-resistant starch layer filtering the blood, nor mad- 
der saponins lysing the red blood cells (RBCs), so there would be much more RBCs in plasma-bound clots in and on the cloth than found on the Shroud (cf. Section 3.4). The average diameter of a RBC is about $8 \mu \mathrm{m}$ [142], and aged bloodstains show a high preservation of RBC integrity [143]. Yet, many completely and smoothly red colored microfibers of $10-20 \mu \mathrm{m}$ diameter were found in bloodstain areas of the Shroud, for instance in the 'lance wound' area (Figure 23), where also an acid heme's charge transfer peak was found in UV-vis spectrometry (Figure S1) [12]. The red Shroud fiber shown in Figure 23 also gave an intense positive test for proteins, while both body-image and non-image fibers of the Shroud tested negative for proteins [7] [141]. Such a red fiber is hard to explain without hemolysate from saponin-induced hemolysis and heme-madder lake formation and abrasion of dried hemolysate and of broken RBCs.

That the red bloodstains would consist of red serum, hypothesized and described as a bilirubin-rich blood clot exudate by Adler [13], is (further) contradicted by the presence of golden-yellow serum fibers on the Shroud (Section 3.3, cf. Section 2.4). Also, if brown or black bloodstains formed by cold acid postmortem blood on pure linen had been touched-up with red madder lake paint or red madder dye-but why? Also in medieval times people knew that real old bloodstains should look brown or black-, it would have been very hard to produce a contour-match not betraying the touch-up operation. Furthermore, if an iron-based madder lake paint was painted on bloodstains, besides brown/black RBCs, also the paint's 0.5 - $1 \mu \mathrm{m} \varnothing$ iron oxide particles and any larger red-ochre particles (iron hydroxide, sand, clay) would probably be discernible on the red fiber, as both red ochre and madder lake absorb much binder [144]-[146]. Conversely, if red madder dye was applied on old bloodstains on pure linen, besides that the resulting color would probably still be darker than the bloodstain color on the Shroud, there would be no or less free heme outside the clots for lack of saponin-induced hemolysis, and thus no or less heme-madder lake formation to account for the loose 'blood globs', varying in size from 5 to $50 \mu \mathrm{m}$ [7], with an FT-IR spectrum as of madder lake (Section 2.3).

\section{Experimental Blood Clot Imprints}

The results of a few experiments show that whole human blood is able to form pinkish red stains with a fluorescent serum margin on starched and madder-dyed linen (Figure 10 and Figure 24). These stains retained their pinkish color when simultaneously formed bloodstains on pure linen turned brown. Note that such pinkish red stains of normal—not postmortem—-blood would not lack potassium or present a translucent acid methemoglobin crystal (cf. Section 3).

\section{Conclusion}

The anomalous features of the Shroud's bloodstains, instead of being evidence against their authenticity, turn out to be very strong evidence for their authenticity, as these anomalies are the consistent specifics of cold acid postmortem blood that formed pinkish red heme-madder lake on a cold-water-resistant madder-dyed cloth such as, most probably, the Shroud. Beside the normal human blood features found in the Shroud's bloodstains, the

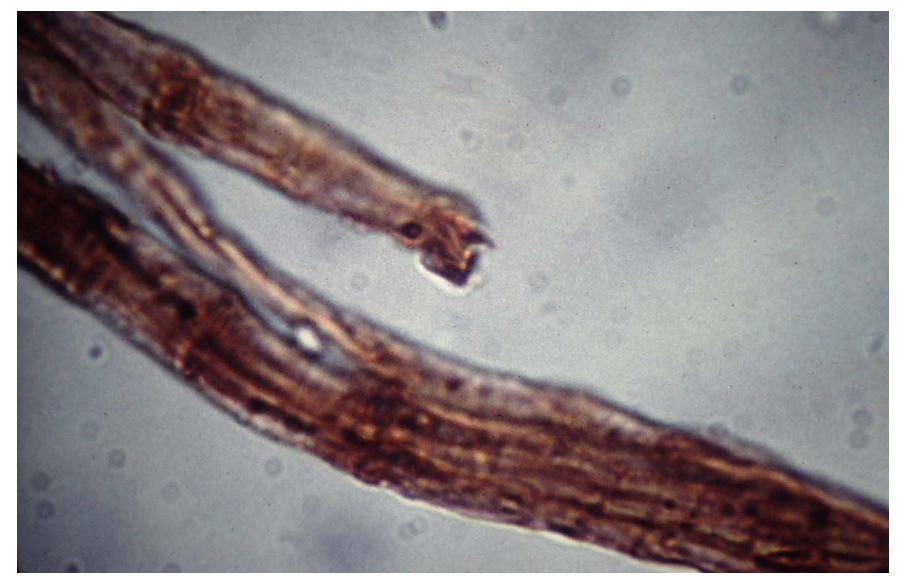

Figure 23. Microscopic appearance of fibers from the 'lance wound' area of the ventral half of the Shroud. From [141] (C2004 Raymond N. Rogers collection, STERA, Inc. 


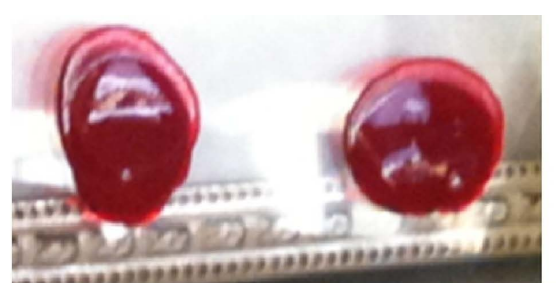

(a)

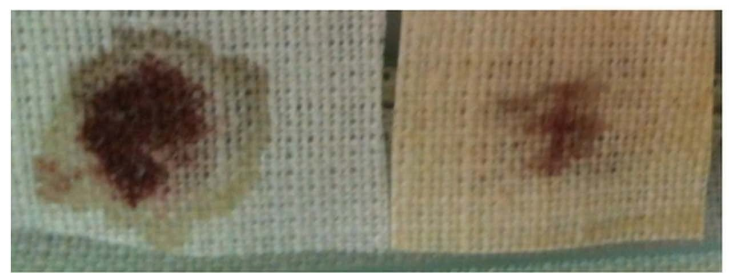

(b)

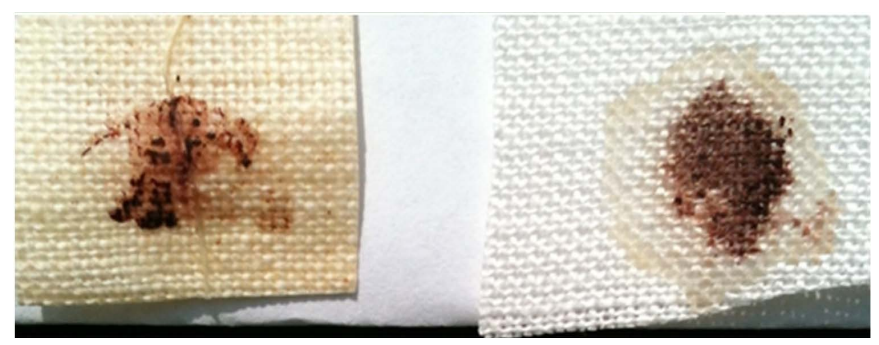

(c)

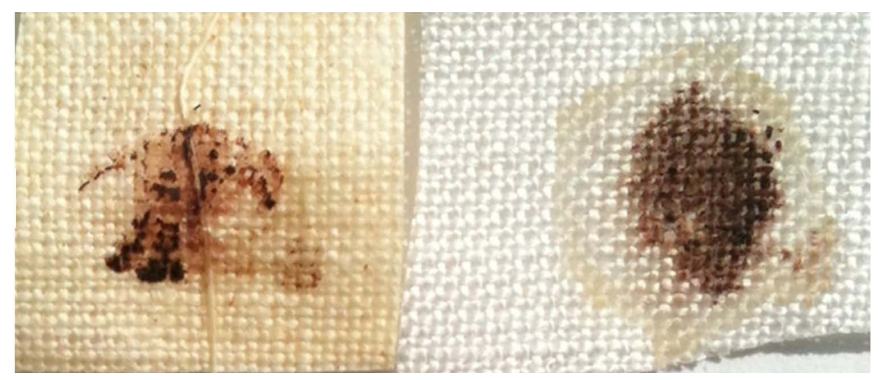

(d)

Figure 24. Vertical clot imprints on pure (oxygen-bleached) and starched-and-madder-dyed linen. (a) 1.5 hours-old human blood clots right before imprinting (placed vertical $30 \mathrm{~min}$ after blood was released from the finger on a horizontal glass plate in a room at $18^{\circ} \mathrm{C}-19^{\circ} \mathrm{C}$ and $60 \%-70 \%$ rel. humidity); (b) non-contact side, 1 day after imprinting; (c) contact side, most loose crusts removed, 15 days after imprinting; (d) idem, 28 days after imprinting. The red/brown flow away from the clot was caused by the manual turning around of the glass plate.

seemingly anomalous UV-vis, UV fluorescence and FT-IR spectra obtained, indicate that the most probable constituent of the pinkish red stains is an acid heme-madder lake. Microscopic and other observations preclude that a red madder lake or red madder dye was painted on to produce or retouch all bloodstains. Especially the fluorescent serum margins of some of the stains, the stains' lack of potassium, and the apparent formation of acid heme-madder lake stains in the right anatomical locations of the body image before this image-consisting of madderless image fibers-was formed, render it highly unlikely that the stains and body image were produced by a medieval artist. Shroud stains containing acid heme and lacking potassium, for lack of reasonable alternatives, virtually must have been formed by acid postmortem blood of which some was clotting and exuding its potassium-rich serum on a relatively cold surface, such as the cold skin of a dead body, possibly that of Jesus Christ. The presence of a coating of retrograded starch and yellow madder dye on the Shroud, which would have filtered and hemolysed the blood, is most clearly evidenced by UV-fluorescence photos of some of the Shroud's water stains, but also the UV-fluorescence color and spectrum of the Shroud background are consistent with the 
presence of a yellow madder dye. The FT-IR spectra of samples from the Shroud background, consistent with the presence of starch and madder, are similar to those from the Shroud corner that was otherwise shown to contain a coating of starch and a yellow dye with the same acidichromism as madder dye, and to be no repair area. A few experiments confirmed that much serum can drain from human blood on a cold surface and that human blood is able to form pinkish stains on starched and madder-dyed linen that remain pinkish while simultaneously formed bloodstains on pure linen turn brown. New scientific investigations on the Shroud of Turin with more modern methods and techniques may further corroborate these conclusions.

\section{Acknowledgements}

I am grateful to T.J. Egan, F.E.G. Guimarães, M.J. Melo, A. Boffi, and V. Bobbarala for answering my questions on the aqueous heme dimer, lignin fluorescence, alizarin and purpurin spectra, acid methemoglobin, and madder root extracts, respectively.

\section{References}

[1] Latendresse, M. Shroud Scope, a Tool to Analyze the Shroud of Turin. http://www.sindonology.org/shroudScope/shroudScope.shtml

[2] Lucotte, G. (2012) Optical and Chemical Characteristics of the Mineral Particles Found on the Face of the Turin Shroud. Scientific Research and Essays, 7, 2545-2553.

http://www.academicjournals.org/article/article1380797812_Lucotte.pdf http://dx.doi.org/10.5897/SRE12.383

[3] Baima Bollone, P. and Gaglio, A. (2000) The Forensic Characteristics of the Blood Marks. In: Scannerini, S. and Savarino, P., Eds., The Turin Shroud, Past, Present and Future, Effatà Editrice, Cantalupa (To), 209-218.

[4] Garza-Valdes, L.A. (2001) The DNA of God? Berkley Books, New York.

[5] Fanti, G. and Gaeta, S. (2013) Il mistero della Sindone. Rizzoli, Milano.

[6] Heller, J.H. and Adler, A.D. (1980) Blood on the Shroud of Turin. Applied Optics, 19, 2742-2744. http://www.shroud.com/pdfs/ssi43part2.pdf http://dx.doi.org/10.1364/AO.19.002742

[7] Heller, J.H. and Adler, A.D. (1981) A Chemical Investigation of the Shroud of Turin. Canadian Society of Forensic Science Journal, 14, 81-103. http://www.shroud.com/pdfs/ssi43part3.pdf http://dx.doi.org/10.1080/00085030.1981.10756882

[8] Morris, R.A., Schwalbe, L.A. and London, J.R. (1980) X-Ray Fluorescence Investigation of the Shroud of Turin. X-Ray Spectrometry, 9, 40-47. http://dx.doi.org/10.1002/xrs.1300090203

[9] Heller, J.H. (1983) Report on the Shroud of Turin. Paperback Edition, Houghton Mifflin Company, Boston.

[10] Kearse, K.P. (2012) Blood on the Shroud of Turin: An Immunological Review. http://www.shroud.com/pdfs/kearse.pdf

[11] Haltadefinizione (2013) La Sindone e Haltadefinizione: Le riprese del 2008. http://www.haltadefinizione.com/it/la-sindone

[12] Gilbert Jr., R. and Gilbert, M.M. (1980) Ultraviolet-Visible Reflectance and Fluorescence Spectra of the Shroud of Turin. Applied Optics, 19, 1930-1936. http://dx.doi.org/10.1364/AO.19.001930

[13] Adler, A.D. (1986) The Origin and Nature of Blood on the Turin Shroud. In: Meacham, W., Ed., Turin Shroud-Image of Christ? Turin Shroud Photographic Exhibition Organising Committee, Hong Kong, 57-59. http://www.shroud.com/pdfs/ssi43part4.pdf

[14] Adler, A.D., Selzer, R. and DeBlase, F. (2002) Further Spectroscopic Investigations of Samples of the Shroud of Turin. In: Minor, M., Adler, A.D. and Piczek, D.I., Eds., The Shroud of Turin-Unraveling the Mystery, Alexander Books, Alexander, 166-181. http://www.shroud.com/pdfs/ssi43part9.pdf

[15] Adler, A.D. (2002) Chemical and Physical Aspects of the Sindonic Images. In: Crispino. D., Ed., Alan D. Adler-The Orphaned Manuscript. A Shroud Spectrum International Special Issue, Effatà Editrice, Turin, 11-27. http://www.shroud.com/pdfs/ssi43part1.pdf

[16] Adler, A.D. (1996) Updating Recent Studies on the Shroud of Turin. In: Orna, M.V., Ed., Archaeological Chemistry: Organic, Inorganic, and Biochemical Analysis, ACS Symposium Series 625, American Chemical Society, Washington DC, 223-228. http://www.shroud.com/pdfs/ssi43part7.pdf http://dx.doi.org/10.1021/bk-1996-0625.ch017

[17] Villarreal, R., Schwortz, B. and Benford, M.S. (2009) Analytical Results on Threads Taken from the Raes Sampling 
Area (Corner) of the Shroud. In: Fanti, G., Ed., The Shroud of Turin-Perspectives on a Multifaceted Enigma, Edizioni Libreria Progetto, Padova, 319-336.

[18] Austin, J.H. and Drabkin, D.L. (1935) Spectrophotometric Studies III. Methemoglobin. Journal of Biological Chemistry, 112, 67-88. http://www.jbc.org/content/112/1/67.short

[19] Pellicori, S.F. (1980) Spectral Properties of the Shroud of Turin. Applied Optics, 19, 1913-1920. http://dx.doi.org/10.1364/AO.19.001913

[20] De Villiers, K.A., Kaschula, C.H., Egan, T.J. and Marques, H.E. (2007) Speciation and Structure of Ferriprotoporphyrin IX in Aqueous Solution: Spectroscopic and Diffusion Measurements Demonstrate Dimerization, but Not $\mu$-Oxo Dimer Formation. Journal of Biological Inorganic Chemistry, 12, 101-117. http://dx.doi.org/10.1007/s00775-006-0170-1

[21] Greer, J.P., Ed. (2009) Wintrobe’s Clinical Hematology, 12th Edition, Lippincott Williams \& Wilkins, Philadelphia.

[22] Clementi, C., Nowik, W., Romani, A., Cibin, F. and Favaro, G. (2007) A Spectrometric and Chromatographic Approach to the Study of Ageing of Madder (Rubia tinctorum L.) Dyestuff on Wool. Analytica Chimica Acta, 596, 46-54. http://dx.doi.org/10.1016/j.aca.2007.05.036

[23] Aceto, M., et al. (2012) First Analytical Evidences of Precious Colourants on Mediterranean Illuminated Manuscripts. Spectrochimica Acta, Part A, 95, 235-245. http://dx.doi.org/10.1016/j.saa.2012.04.103

[24] Miliani, C., Romani, A. and Favaro, G. (2000) Acidichromic Effects in 1,2-di- and 1,2,4-tri-Hydroxyanthraquinones. A Spectrophotometric and Fluorimetric Study. Journal of Physical Organic Chemistry, 13, 141-150. http://dx.doi.org/10.1002/(SICI)1099-1395(200003)13:3<141::AID-POC220>3.0.CO;2-J

[25] Museum of Fine Arts Boston. Madder. Conservation \& Art Materials Encyclopedia Online. http://cameo.mfa.org/wiki/Madder

[26] Feller, R.L. (2011) Comments on the Measurement of "Yellowness” in Pulp and Paper. The Book and Paper Group Annual 6. http://cool.conservation-us.org/coolaic/sg/bpg/annual/v06/bp06-04.html

[27] Miller, V.D. and Pellicori, S.F. (1981) Ultraviolet Fluorescence Photography of the Shroud of Turin. Journal of Biological Photography, 49, 71-85.

[28] Iram, A. and Naeem, A. (2013) Detection and Analysis of Protofibrils and Fibrils of Hemoglobin: Implications for the Pathogenesis and Cure of Heme Loss Related Maladies. Archives of Biochemistry and Biophysics, 533, 69-78. http://dx.doi.org/10.1016/j.abb.2013.02.019

[29] Liu, W., Guo, X. and Guo, R. (2005) The Interaction of Hemoglobin with Hexadecyltrimethylammonium Bromide. International Journal of Biological Macromolecules, 37, 232-238. http://dx.doi.org/10.1016/j.ijbiomac.2005.11.007

[30] Claro, A., et al. (2008) The Use of Microspectrofluorimetry for the Characterization of Lake Pigments. Talanta, 74, 922-929. http://dx.doi.org/10.1016/j.talanta.2007.07.036

[31] Goldoni, C. (2008) The Shroud of Turin and the Bilirubin Bloodstains. http://www.ohioshroudconference.com/papers/p04.pdf

[32] Jeffers, L.A. and Malito, M.L. (1996) On-line Measurement of Lignin in Wood Pulp by Color Shift of Fluorescence. US Patent 5486915.

[33] Soltanizadeh, N. and Kadivar, M. (2012) Role of Globin Moiety in the Chemical Structure of Curing Pigment. Journal of Agricultural and Food Chemistry, 60, 4718-4724.

http://soltanizadeh.iut.ac.ir/sites/soltanizadeh.iut.ac.ir/files/file_pubwdet/role_of_globin_moiety_in_the_chemical_stru cture_of_curing_pigment_0.pdf http://dx.doi.org/10.1021/jf300023s

[34] Van der Hoeven, A.A.M. (2014) Authentic Acid Blood Mordanted the Madder-Dyed Shroud of Turin Pinkish Red before Image Formation-Jesus Was Dead. https://www.academia.edu/8431835/Authentic_acid_blood_mordanted_the_madder-dyed_Shroud_of_Turin_pinkis h_red_before_image_formation_-_Jesus_was_dead

[35] Velapoldi, R.A. and Menis, O. (1971) Formation and Stabilities of Free Bilirubin and Bilirubin Complexes with Transition and Rare-Earth Elements. Clinical Chemistry, 17, 1165-1170. http://www.clinchem.org/content/17/12/1165.full.pdf

[36] Zucker, S.D., Goessling, W., Bootle, E.J. and Sterritt, C. (2001) Localization of Bilirubin in Phospholipid Bilayers by Parallax Analysis of Fluorescence Quenching. Journal of Lipid Research, 42, 1377-1388.

http://www.jlr.org/content/42/9/1377.full.pdf+html

[37] Berry, C.S. (2013) The Turin Shroud: Spotlight on a Particular-Mark Stain. Some Call It Blood; I Call It CLACK... http://shroudofturinwithoutallthehype.wordpress.com/2012/06/27/the-turin-shroud-spotlight-on-a-particular-mark-stain -some-call-it-blood-i-call-it-clack/ 
[38] Chernoff, D.A., Hochstrasser, R.M. and Steele, A.W. (1980) Geminate Recombination of $\mathrm{O}_{2}$ and Hemoglobin. Proceedings of the National Academy of Sciences of the USA, 77, 5606-5610. http://www.pnas.org/content/77/10/5606.full.pdf http://dx.doi.org/10.1073/pnas.77.10.5606

[39] Lister, T., Wright, P.A. and Chappell, P.H. (2012) Optical Properties of Human Skin. Journal of Biomedical Optics, 17, 090901. http://dx.doi.org/10.1117/1.JBO.17.9.090901

[40] Bacci, M., Linari, R., Agati, G. and Fusi, F. (1989) UV Excitable Fluorescence of Lumirubin. Journal of Photochemistry and Photobiology B: Biology, 3, 419-427. http://dx.doi.org/10.1016/1011-1344(89)80046-6

[41] Fanti, G. (2008) Body Image Formation Hypotheses Based on Corona Discharge: Discussion. http://www.ohioshroudconference.com/papers/p15.pdf

[42] Kearse, K.P. and Heimburger, T. (2013) The Shroud Blood Science of Dr. Pierluigi Baima Bollone: Another Look at Potassium, among Other Things. http://shroudofturin.files.wordpress.com/2013/12/bbk-7.pdf

[43] Fanti, G., Calliari, I. and Canovaro, D. (2012) Analysis of Micro-Particles Vacuumed from the Turin Shroud. http://www.dii.unipd.it/-giulio.fanti/research/Sindone/Paper\%20Valencia.pdf

[44] McCrone, W.C. (1990) The Shroud of Turin: Blood or Artist’s Pigment? Accounts of Chemical Research, 23, 77-83. http://www.mcri.org.php53-15.dfw1-1.websitetestlink.com/uploads/the_microscope_shroud_small-1422560933.pdf http://dx.doi.org/10.1021/ar00171a004

[45] Schwalbe, L.A. and Rogers, R.N. (1982) Physics and Chemistry of the Shroud of Turin, a Summary of the 1978 Investigations. Analytica Chimica Acta, 135, 3-49. http://dx.doi.org/10.1016/S0003-2670(01)85263-6

[46] Ferner, R.E. (2008) Post-Mortem Clinical Pharmacology. British Journal of Clinical Pharmacology, 66, $430-443$. http://onlinelibrary.wiley.com/doi/10.1111/j.1365-2125.2008.03231.x/full http://dx.doi.org/10.1111/j.1365-2125.2008.03231.x

[47] Weedn, V.W., Siebert Jr., C.F. and Prahlow, J.A. (2012) Postmortem Chemistry. Taylor and Francis Group, LLC. http://web.archive.org/web/20150327234542/http:/www.attorneygeneral.jus.gov.on.ca/inquiries/elliotlake/exhibits/pdf/ 09242-DMQ_E000003331.pdf

[48] Rogers, K.M.A. and McCutcheon, K. (2015) Four Steps to Interpreting Arterial Blood Gases. Journal of Perioperative Practice, 25, 46-52. http://www.ingentaconnect.com/content/afpp/jpp/2015/00000025/00000003/art00008

[49] Negrusz, A. and Cooper, G. (2013) Clarke’s Analytical Forensic Toxicology. 2nd Edition, Pharmaceutical Press, London.

[50] Steinhardt, J. and Hiremath, C.B. (1967) A Comparison of the Resistance of Human and Horse Ferrihemoglobin to Acid Denaturation. Journal of Biological Chemistry, 242, 1294-1301. http://www.jbc.org/content/242/6/1294.full.pdf

[51] Sterns, R.H., Cox, M., Feig, P.U. and Singer, I. (1981) Internal Potassium Balance and the Control of the Plasma Potassium Concentration. Medicine, 60, 339-354.

http://journals.lww.com/md-journal/Citation/1981/09000/Internal Potassium Balance and the Control of the.2.aspx http://dx.doi.org/10.1097/00005792-198109000-00002

[52] Sturner, W.Q. (2006) Chemical Considerations. In: Spitz, W.U. and Spitz, D.J., .Eds., Spitz and Fisher's Medicolegal Investigation of Death, 4th Edition, Charles C. Tomas, Springfield IL, 128-148.

[53] Coe, J.I. (1977) Postmortem Chemistry of Blood, Cerebrospinal Fluid, and Vitreous Humor. In: Tedeschi, C.G., Tedeschi, L.G. and Eckert, W.G., Eds., Forensic Medicine: A Study in Trauma and Environmental Hazards, Saunders, Philadelphia, 1033-1060.

[54] Lavoie, G.R., Lavoie, B.B., Donovan, V.J. and Ballas, J.S. (1983) Blood on the Shroud of Turin: Part II-The Importance of Time in the Transfer of Blood Clots to Cloth as Distinctive Clot Images. Shroud Spectrum International, 8, 2-10. http://www.shroud.com/pdfs/ssi08part3.pdf

[55] Lind, A. and Antonacci, M. (2014) Hypothesis That Explains the Shroud's Unique Blood Marks and Several Critical Events in the Gospels. http://www.shroud.com/pdfs/stllindpaper.pdf https://www.youtube.com/watch?v=X1VdmyHXOY0

[56] Lu, G., An, Z. and Li, J. (2004) Biogenic Capsules Made of Proteins and Lipids. Biochemical and Biophysical Research Communications, 315, 224-227. http://dx.doi.org/10.1016/j.bbrc.2004.01.042

[57] Grossi, A. (2012) Jewish Shrouds and Funerary Customs: A Comparison with the Shroud of Turin. https://www.academia.edu/2427474/Jewish_Shrouds_and_Funerary_Customs_a_Comparison_with_the_Shroud_of_T urin_in_1st_International_Congress_on_the_Holy_Shroud_in_Spain_Valencia_April_28-30_2012_ed._Centro_Espa\% C3\%B1ol_de_Sindonologia_CES_

[58] Kohler, K. (1906) Burial. Jewish Encyclopedia. http://www.jewishencyclopedia.com/articles/3842-burial\#anchor8

[59] Murti, V.V.S., Seshadri, T.R. and Sivakumaran, S. (1970) A Study of Madder, the Roots of Rubia tinctorum Linn. 
Indian Journal of Chemistry, 8, 779-782.

[60] Dengre, R.G., Patel, K.N. and Chauhan, M.B. (1993) Comparative Studies of Rubia cordifolia Linn. and Rubia tinctorum Linn (Rubiaceae). Ancient Science of Life, 13, 165-179. http://www.ncbi.nlm.nih.gov/pmc/articles/PMC3336544/pdf/ASL-13-165.pdf

[61] Reeve, R.M. (1951) Histochemical Tests for Polyphenols in Plant Tissues. Stain Technology, 26, 91-96. http://informahealthcare.com/doi/abs/10.3109/10520295109113187 http://dx.doi.org/10.3109/10520295109113187

[62] Wallace, W.J., Houtchens, R.A., Maxwell, J.C. and Caughey, W.S. (1982) Mechanism of Autooxidation for Hemoglobins and Myoglobins. Promotion of Superoxide Production by Protons and Anions. Journal of Biological Chemistry, 257, 4966-4977. http://www.jbc.org/content/257/9/4966.full.pdf

[63] Winter, R.W., et al. (1995) Hydroxy-Anthraquinones as Antimalarial Agents. Bioorganic and Medical Chemistry Letters, 5, 1927-1932. http://dx.doi.org/10.1016/0960-894X(95)00326-O

[64] Winter, R.W., et al. (1996) Potentiation of the Antimalarial Activity of Rufigallol. Antimicrobial Agents and Chemotherapy, 40, 1408-1411. http://aac.asm.org/content/40/6/1408.full.pdf

[65] Sack, S.P., Tahk, F.C. and Peters Jr., T. (1981) A Technical Examination of an Ancient Egyptian Painting on Canvas. Studies in Conservation, 26, 15-23. http://dx.doi.org/10.1179/sic.1981.26.1.15

[66] Orska-Gawrys, J., et al. (2003) Identification of Natural Dyes in Archeological Coptic Textiles by Liquid Chromatography with Diode Array Detection. Journal of Chromatography A, 989, 239-248. http://dx.doi.org/10.1016/S0021-9673(03)00083-9

[67] Sabnis, R.W. (2010) Handbook of Biological Dyes and Stains-Synthesis and Industrial Applications. John Wiley \& Sons, Hoboken. http://dx.doi.org/10.1002/9780470586242

[68] Santa Cruz Biotechnology (2010) Purpurin. http://datasheets.scbt.com/sc-205822.pdf

[69] Fanti, G., et al. (2005) Evidences for Testing Hypotheses about the Body Image Formation of the Turin Shroud. http://www.shroud.com/pdfs/doclist.pdf

[70] Fanti, G. (2011) Hypotheses Regarding the Formation of the Body Image on the Shroud of Turin: A Critical Compendium. Journal of Imaging Science and Technology, 55, 060507. http://dx.doi.org/10.2352/j.imagingsci.technol.2011.55.6.060507

[71] Van Haelst, R. (1997) Radiocarbon Dating the Shroud-A Critical Statistical Analysis. http://www.shroud.com/vanhels3.htm

[72] Van Haelst, R. (2002) Radiocarbon Dating the Shroud of Turin. http://www.sindone.info/VHAELST6.PDF

[73] Van Haelst, R. (2011) Analyzing Radiocarbon Data Using Burr Statistics. http://www.shroud.com/pdfs/vanhaelst8.pdf

[74] Riani, M., Atkinson, A.C., Fanti, G. and Crosilla, F. (2013) Regression Analysis with Partially Labelled Regressors: Carbon Dating of the Shroud of Turin. Statistics and Computing, 23, 551-561. http://dx.doi.org/10.1007/s11222-012-9329-5

[75] Manservigi, F. and Morini, E. (2014) The Hypotheses about the Roman Flagrum: Some Clarifications. https://www.academia.edu/10173083/Shroud_of_Turin_The_Controversial_InterSection_of_Faith_and_Science._The_ hypotheses_about_the_Roman_flagrum._Some_clarifications

[76] Takeichi, S., Tokunaga, I., Hayakumo, K. and Maeiwa, M. (1986) Fluidity of Cadaveric Blood after Sudden Death: Part III-Acid-Base Balance and Fibrinolysis. American Journal of Forensic Medicine and Pathology, 7, 35-38. http://dx.doi.org/10.1097/00000433-198603000-00007

[77] Müllertz, S. (1953) Fibrinolytic Activity of Human Blood after Death. Acta Physiologica Scandinavica, 27, $265-271$. http://dx.doi.org/10.1111/j.1748-1716.1953.tb00942.x

[78] De la Torre, J. and Sholar, A. (2006) Wound Healing: Chronic Wounds. Medscape. http://emedicine.medscape.com/article/1298452-overview\#aw2aab6b3

[79] Zugibe, F.T. (1989) The Man on the Shroud Was Washed. Sindon N. S.1. http://www.crucifixion-shroud.com/Washed.htm

[80] Villarreal, R. and Villarreal, R. (2012) A New Look at the Validity of the Carbon-14 Dating of the Shroud. http://www.shroud.com/pdfs/villarrealvppt.pdf http://www.shroud.com/pdfs/villarrealvtxt.pdf

[81] Lavoie, G.R., Lavoie, B.B., Klutstein, D. and Regan, J. (1982) In Accordance with Jewish Burial Custom, The Body of Jesus Was Not Washed. Shroud Spectrum International, 3, 8-17. http://www.shroud.com/pdfs/ssi03part4.pdf

[82] Tieu, B.H., Holcomb, J.B. and Schreiber, M.A. (2007) Coagulopathy: Its Pathophysiology and Treatment in the Injured Patient. World Journal of Surgery, 31, 1055-1065. http://dx.doi.org/10.1007/s00268-006-0653-9 
[83] Levrat, A., et al. (2008) Evaluation of Rotation Thrombelastography for the Diagnosis of Hyperfibrinolysis in Trauma Patients. British Journal of Anaesthesia, 100, 792-797. http://bja.oxfordjournals.org/content/100/6/792.full.pdf+htmlaen083 http://dx.doi.org/10.1093/bja/aen083

[84] Brillante, C., Fanti, G. and Marinelli, E. (2002) Bloodstains Characteristics to Be Considered in Laboratory Reconstruction of the Turin Shroud. http://www.dii.unipd.it/-giulio.fanti/research/Sindone/Blood\%20paper\%2019\%20Marin.pdf

[85] Vial, G. (1989) Le Linceul de Turin—Étude Technique. Centre International d'Étude des Textiles Anciens—Bulletin, 67, 11-24.

[86] Wilson, I. (1990) Recent Publications. British Society for the Turin Shroud Newsletter, 26. http://www.shroud.com/pdfs/n26part9.pdf

[87] Rogers, R.N. and Arnoldi, A. (2002) Scientific Method Applied to the Shroud of Turin. http://www.shroud.com/pdfs/rogers2.pdf

[88] Rogers, R.N. (2004) Frequently Asked Questions (FAQs). http://www.shroud.com/pdfs/rogers5faqs.pdf

[89] Adler, A.D. (1999) The Nature of the Body Images on the Shroud of Turin. http://www.shroud.com/pdfs/adler.pdf

[90] Rogers, R.N. (2001) Comments on the Book “The Resurrection of the Shroud” by Mark Antonacci. http://www.shroud.com/pdfs/rogers.pdf

[91] Swamy, P.M. (2008) Laboratory Manual on Biotechnology. Rastogi, Meerut.

[92] Panigrahi, R. and Bhatnagar, S. (2015) Cytotoxic, Phytochemical and Antioxidant Potential of Marshy Herb Enhydra fluctuans Lour. International Journal of Ethnobiology \& Ethnomedicine, 1, 1-6. http://www.advancejournals.org/uploads/9cc83d5b26af1ec7239a05bef2941a87c05b4eb5d06fe97ec415b9825deb4b56/ Manuscript/5444.pdf

[93] Bracaglia, G. Raes Problematic Threads. http://holyshroudguild.org/drraes-problematic-threads.html

[94] Bracaglia, G. Sister Damian of the Cross, OCD (Dr. Eugenia Nitowski). http://holyshroudguild.org/dr-nitowski-new.html

[95] Benford, M.S. and Marino, J.G. (2000) Evidence for the Skewing of the C-14 Dating of the Shroud of Turin Due to Repairs. http://www.shroud.com/pdfs/marben.pdf

[96] Benford, M.S. and Marino, J.G. (2002) Textile Evidence Supports Skewed Radiocarbon Date of Shroud of Turin. http://www.shroud.com/pdfs/textevid.pdf

[97] Benford, M.S. and Marino, J.G. (2008) Discrepancies in the Radiocarbon Dating Area of the Turin Shroud. http://www.ohioshroudconference.com/papers/p09.pdf

[98] Marino, J.G. and Benford, M.S. (2008) Invisible Mending and the Turin Shroud: Historical and Scientific Evidence. http://www.ohioshroudconference.com/papers/p11.pdf

[99] Rogers, R.N. (2005) Studies on the Radiocarbon Sample from the Shroud of Turin. Thermochimica Acta, 425, $189-194$. http://www.shroud.it/ROGERS-3.PDF http://dx.doi.org/10.1016/j.tca.2004.09.029

[100] Morgan, J.M. (2012) Digital İmage Processing Techniques Demonstrating the Anomalous Nature of the Radiocarbon Dating Sample Area of the Shroud of Turin. Scientific Research and Essays, 7, 2641-2655.

http://www.academicjournals.org/article/article1380798975_Morgan.pdf http://dx.doi.org/10.5897/SRE12.375

[101] Maimonides (1170-80 AD) Mishneh Torah, Kli Hamikdash, Chapter 8, Halacha 4-5. http://www.chabad.org/library/article_cdo/aid/1008233/jewish/Chapter-8.htm

[102] Van der Hoeven, A.A.M. (2011) The Seam and Missing Corners of the Turin Shroud as Characteristics of John Mark’s Temple Garment.

https://www.academia.edu/1536599/The_seam_and_missing_corners_of_the_Turin_Shroud_as_characteristics_of_Joh n Marks temple garment

[103] Van der Hoeven, A.A.M. (2012) Internal Selvedge in Starched and Dyed Temple Mantle—No invisible repair in Turin Shroud-No Maillard reaction.

https://www.academia.edu/1536606/Internal_selvedge_in_starched_and_dyed_temple_mantle_-_No_invisible_repair_i n_Turin_Shroud_-_No_Maillard_reaction

[104] Pliny the Elder ( $1^{\text {st }}$ c. AD) Naturalis Historia. On a Fine Acid Paste of "Pollinis Flore" (= lit. "the Flower of Pollen", Probably the Starch Granules Washable from Flour): Book XIII, ch. 23 in the Latin Text, and ch. 26 in the English Text. http://www.perseus.tufts.edu/hopper/text?doc=Perseus:text:1999.02.0138:book=13:chapter=23 http://www.perseus.tufts.edu/hopper/text?doc=Perseus\%3Atext\%3A1999.02.0137\%3Abook\%3D13\%3Achapter\%3D26 
[105] Nicholson, P.T. and Shaw, I., Eds. (2000) Ancient Egyptian Materials and Technology. Cambridge University Press, Cambridge, 238.

[106] Reeve, R.M. (1963) Estimation of Extra-Cellular Starch of Dehydrated Potatoes. Journal of Food Science, 28, $198-206$. http://dx.doi.org/10.1111/j.1365-2621.1963.tb00184.x

[107] Tester, R.F. and Morrison, W.R. (1990) Swelling and Gelatinization of Cereal Starches. I. Effects of Amylopectin, Amylose, and Lipids. Cereal Chemistry, 67, 551-557. http://www.aaccnet.org/publications/cc/backissues/1990/Documents/67_551.pdf

[108] Gidley, M.J., Cooke, D., Darke, A.H. and Hoffmann, R.A. (1995) Molecular Order and Structure in Enzyme-Resistant Retrograded Starch. Carbohydrate Polymers, 28, 23-31. http://dx.doi.org/10.1016/0144-8617(96)81387-7

[109] Gulmini, M., et al. (2013) Identification of Dyestuffs in Historical Textiles: Strong and Weak Points of a Non-Invasive Approach. Dyes and Pigments, 98, 136-145. http://dx.doi.org/10.1016/j.dyepig.2013.02.010

[110] Guerreschi, A. and Salcito, M. (2005) Further Studies on the Scorches and the Watermarks. http://www.shroud.com/pdfs/aldo4.pdf

[111] Case, T.W. (1996) The Shroud of Turin and the C-14 Dating Fiasco. White Horse Press, Cincinnati.

[112] Kunwar, R.M., Uprety, Y., Burlakoti, C., Chowdhary, C.L. and Bussmann, R.W. (2009) Indigenous Use and Ethnopharmacology of Medicinal Plants in Far-West Nepal. Ethnobotany Research and Applications, 7, 5-28. http://scholarspace.manoa.hawaii.edu/bitstream/handle/10125/12503/i1547-3465?sequence=1

[113] Santa Cruz Biotechnology (2010) Alizarin. http://datasheets.scbt.com/sc-214519.pdf

[114] Guibault, G.G. (1990) Assay of Organic Compounds. In: Guibault, G.G., Ed., Practical Fluorescence. Modern Monographs in Analytical Chemistry 3, 2nd Edition, Marcel Dekker Inc., New York, 231-366.

[115] Fanti, G. (2008) Round Table on C-14: Discussion about a Possible New Test on the Shroud. http://www.ohioshroudconference.com/papers/p18.pdf

[116] Fanti, G. and Basso, R. (2008) Statistical Analysis of Dusts Taken from Different Areas of the Turin Shroud. http://www.ohioshroudconference.com/papers/p16.pdf

[117] Breault, R. (2008) 2008 C 14 Forum. https://www.youtube.com/watch?v=00A44IthPSs

[118] Schoonover, J.R. (2014) Summary of Shroud FTIR Analysis. Presentation Slides, Presented by R. Villarreal at the Shroud Conference in St. Louis. http://www.shroud.com/pdfs/stlschoonoverppt.pdf

[119] Fanti, G. (2013) Non-Destructive Dating of Ancient Flax Textiles by Means of Vibrational Spectroscopy. Vibrational Spectroscopy, 67, 61-70. http://dx.doi.org/10.1016/j.vibspec.2013.04.001

[120] Fanti, G. (2015) Optical Features of Flax Fibers Coming from the Turin Shroud. SHS Web of Conferences, $15,00004$. http://dx.doi.org/10.1051/shsconf/20151500004

[121] Schwortz, B.M. (1982) Mapping of Research Test-Point Areas on the Shroud of Turin. http://www.shroud.com/mapping.htm http://www.shroud.com/maptap2d.htm

[122] Bella, M., Garlaschelli, L. and Samperi, R. (2015) There Is No Mass Spectrometry Evidence That the C14 Sample from the Shroud of Turin Comes from a "Medieval Invisible Mending”. Thermochimica Acta, 617, 169-171. http://dx.doi.org/10.1016/j.tca.2015.08.002

[123] Flury-Lemberg, M. (2007) The Invisible Mending of the Turin Shroud, the Theory and the Reality. British Society for the Turin Shroud Newsletter, 65. http://www.shroud.com/pdfs/n65part5.pdf

[124] Camera, E., Ludovici, M., Galante, M., Sinagra, J. and Picardo, M. (2010) Comprehensive Analysis of the Major Lipid Classes in Sebum by Rapid Resolution High-Performance Liquid Chromatography and Electrospray Mass Spectrometry. Journal of Lipid Research, 51, 3377-3388. http://dx.doi.org/10.1194/jlr.D008391

[125] NIST Chemistry Webbook. 9-Hexadecenoic Acid. http://webbook.nist.gov/cgi/cbook.cgi?ID=C2091294\&Units=SI\&Mask=200\#Mass-Spec

[126] Royal Society of Chemistry. Textile Conservation Case Study-The Victory Sail. http://www.rsc.org/Education/Teachers/Resources/Inspirational/resources/3.3.3.pdf

[127] Quiles, A. et al. (2014) Embalming as a Source of Contamination for Radiocarbon Dating of Egyptian Mummies: On a New Chemical Protocol to Extract Bitumen. ArchéoSciences, 38. http://www.cairn.info/revue-archeosciences-2014-1-page-135.htm

[128] Poiana, M.-A., et al. (2015) Use of ATR-FTIR Spectroscopy to Detect the Changes in Extra Virgin Olive Oil by Adulteration with Soybean Oil and High Temperature Heat Treatment. Open Chemistry, 13. http://dx.doi.org/10.1515/chem-2015-0110

[129] Nitowski, E., Sister Damian of the Cross OCD (1986) Handwritten Letter to Father Rinaldi. 
http://www.holyshroudguild.org/sister-damian-of-the-cross-ocd-dr-eugenia-nitowski.html

[130] Fanti, G. and Faccini, B. Sindone: La scienza spiega la fede-Turin Shroud: Science Explains Faith. http://www.dii.unipd.it/-giulio.fanti/research/Sindone/Mostra\%20Sindone.pdf

[131] Baima Bollone, P. and Gaglio, A. (1984) Demonstration of Blood, Aloes and Myrrh on the Holy Shroud with İmmunofluorescence Techniques. Shroud Spectrum International, 13. http://www.shroud.com/pdfs/ssi13part3.pdf

[132] Fanti, G. et al. (2010) Microscopic and Macroscopic Characteristics of the Shroud of Turin Image Superficiality. Journal of Imaging Science and Technology, 45, 040201. http://www.ligklaedet.dk/images/SUPERFICIALITY\%20published\%20JIST.pdf http://dx.doi.org/10.2352/J.ImagingSci.Technol.2010.54.4.040201

[133] Jauneau, A., et al. (1992) Differential Extractability of Calcium and Pectic Substances in Different Wall Regions of Epicotyl Cells in Young Flax Plants. Journal of Histochemistry \& Cytochemistry, 40, 1183-1189. http://jhc.sagepub.com/content/40/8/1183.full.pdf http://dx.doi.org/10.1177/40.8.1377735

[134] Liu, L., Fishman, M.L., Hicks, K.B. and Kende, M. (2005) Interaction of Various Pectin Formulations with Porcine Colonic Tissues. Biomaterials, 26, 5907-5916. http://nal.usda.gov/download/37497/PDF http://dx.doi.org/10.1016/j.biomaterials.2005.03.005

[135] Kalyoncu, F., Cetin, B. and Saglam, H. (2006) Antimicrobial Activity of Common Madder (Rubia tinctorum L.). Phytotherapy Research, 20, 490-492. http://dx.doi.org/10.1002/ptr.1884

[136] Naidu, K.C., Lalam, R. and Bobbarala, V. (2009) Antimicrobial Agents from Rubia Cordifolia and Glycyrrhiza Glabra against Phytopathogens of Gossypium. International Journal of PharmTech Research, 1, 1512-1518. https://www.researchgate.net/publication/228630416 Antimicrobial agents from Rubia cordifolia and Glycyrrhiza glabra_against_phytopathogens_of_Gossypium

[137] Tsang, P.W., Wong, A.P., Yang, H.P. and Li, N.F. (2013) Purpurin Triggers Caspase-Independent Apoptosis in Candida dubliniensis Biofilms. PLoS One, 8, e86032. http://dx.doi.org/10.1371/journal.pone.0086032

[138] Sabnis, R.W. (2008) Handbook of Acid-Base İndicators. CRC Press, New York.

[139] Yang, M., Zhang, Y., Ji, W. and Hao, F. (2010) Isolation and Identification of the Insecticidal Constituent from Rubia cordifolia L. Agrochemicals, 12. http://www.en.cnki.com.cn/Article_en/CJFDTOTAL-NYZZ201012005.htm

[140] Néss Proaño Gaibor de Vries, A. (2011) Rubiaceae: Dyestuffs, Repellents and Museum Bugs. http://www.collectiewijzer.nl/2011/02/24/rubiaceae-dyestuff-repellents-and-museumbugs/

[141] Rogers, R.N. (2008) A Chemist's Perspective on the Shroud of Turin. Barrie M. Schwortz, USA.

[142] Dao, M., Limm, C.T. and Suresh, S. (2003) Mechanics of the Human Red Blood Cell Deformed by Optical Tweezers. Journal of the Mechanics and Physics of Solids, 51, 2259-2280. https://www.techylib.com/en/view/breakfastclerk/mechanics_of_the_human_red_blood_cell_deformed_by_optical http://dx.doi.org/10.1016/j.jmps.2003.09.019

[143] Hortolà, P. (1992) Sem Analysis of Red Blood Cells in Aged Human Bloodstains. Forensic Science International, 55, 139-159. http://dx.doi.org/10.1016/0379-0738(92)90120-L

[144] McCrone Associates, Inc. McCrone Atlas of Microscopic Particles. http://www.mccroneatlas.com/

[145] McCrone, W.C. (1999) Judgement Day for the Shroud of Turin. Prometheus Books, New York.

[146] Janson, J. Essential Vermeer 2.0—Vermeer’s Palet. Red Ochre, Madder Lake. http://www.essentialvermeer.com/palette/palette_vermeer'_palette.html\#.VlWOiHmFOUk

[147] Clementi, C., et al. (2008) Vibrational and Electronic Properties of Painting Lakes. Applied Physics A, 92, 25-33. http://dx.doi.org/10.1007/s00339-008-4474-6

[148] Brosseau, C.L., Casadio, F. and Van Duyne, R.P. (2011) Revealing the Invisible: Using Surface-Enhanced Raman Spectroscopy to Identify Minute Remnants of Color in Winslow Homer's Colorless Skies. Journal of Raman Spectroscopy, 42, 1305-1310.

[149] Philadelphia Museum of Art (2013, 2014) IOD00201 Madder, Area 3, Natural Red 8, PMA\# B-46, Tran. In: Price, B. and Pretzel, B., Eds., Infrared and Raman Users Group Spectral Database online Edition. http://www.irug.org/jicamp-details?id=176

[150] Jumper, E.J., et al. (1984) A Comprehensive Examination of the Various Stains and İmages on the Shroud of Turin. In: Lambert, J.B., Ed., Archaeological Chemistry-III, Advances in Chemistry Series 205, American Chemical Society, Washington DC, 447-479. http://dx.doi.org/10.1021/ba-1984-0205.ch022

[151] Jackson, J.P. (2005) Response to Mark Antonacci’s Request. http://web.archive.org/web/20110515000000*/http:/www.resurrectionoftheshroud.com/John_Jackson_s_Response.doc 
[152] Adler, A.D., Whanger, A. and Whanger, M. (1997) Concerning the Side Strip on the Shroud of Turin. http://www.shroud.com/adler2.htm

[153] Heimburger, T. (2009) Cotton in Raes/Radiocarbon Threads: The Example of Raes \#7. http://www.shroud.com/pdfs/thibaultr7part1.pdf http://www.shroud.com/pdfs/fantir7appendix.pdf

[154] Svensson, N. (2008) Light Microscopy Study of 24 Samples Originating from the Shroud of Turin. http://www.ligklaedet.dk/images/Light\%20microscopy\%20of\%20fibers\%20by\%20Niels\%20Svensson.pdf

[155] Van Haelst, R. (1997) The Red Stains on the Lier and Other Shroud Copies. http://www.shroud.com/vanhels2.htm

[156] Adler, A.D. (2000) The Shroud Fabric and the Body İmage: Chemical and Physical Characteristics. In: Scannerini, S. and Savarino, P., Eds., The Turin Shroud: Past, Present and Future, Effatà Editrice, Cantalupa (To), 51-73. http://www.shroud.com/pdfs/ssi43part11.pdf

[157] Maloney, P.C. (1998) Science, Archaeology, and the Shroud of Turin. Approfondimento Sindone. http://www.freeinquiry.com/skeptic//shroud/as/maloney.html

[158] Maloney, P.C. (2008) What Went Wrong with the Shroud’s Radiocarbon Date? Setting İt All in Context. https://www.shroud.com/pdfs/ohiomaloneypaper.pdf

[159] McCrone, W.C. and Skirius, C. (1980) Light Microscopical Study of the Turin "Shroud” I. The Microscope, 28, 105113.

[160] Antonacci, M. and Heimburger, T. (2005) Private Internet Debate Challenges Ray Rogers’ Thermochimica Acta Paper. http://www.shroud.com/pdfs/debate.pdf

[161] Adler, A.D. (1998) Soundfile of Presentation in Shroud Symposium Dallas. http://shrouduniversity.com/podcasts/aladler.mp3

[162] Heimburger, T. (2008) A Detailed Critical Review of the Chemical Studies on the Turin Shroud. http://www.shroud.com/pdfs/thibault\%20final\%2001.pdf

[163] Jackson, J.P., Propp, K. and Fornof, D.R. (2000) On the Scientific Validity of the Shroud's Radiocarbon Date. Proceedings of the 1999 Shroud of Turin International Research Conference, Richmond, Virginia, Magisterium Press, Glen Allen, 283-301.

[164] Søvik, A.O. (2013) The Shroud of Turin-A Critical Assessment. http://www.academia.edu/7236952/The_Shroud_of_Turin___A_Critical_Assessment

[165] Flury-Lemberg, M. (2000) Die Leinwand des Turiner Grabtuches zum technischen Befund. In: Scannerini, S. and Savarino, P., Eds., The Turin Shroud, Past, Present and Future, Effatà Editrice, Cantalupa, 21-43.

[166] Breault, R. (2008) 2008 Robert Villareal. https://www.youtube.com/watch?v=86wWOMGqsWQ

[167] Farey, H. (2013) The Mystery of the İnvisible Patch. British Society for the Turin Shroud Newsletter, 78. http://shroud.com/pdfs/n78part9.pdf

[168] Kohlbeck, J.A. and Nitowski, E.L. (1986) New Evidence May Explain Image on Shroud of Turin: Chemical Tests Link Shroud to Jerusalem. Biblical Archaeology Review, 12, 18-29. http://members.bib-arch.org/search.asp?PubID=BSBA\&Volume=12\&Issue=4\&ArticleID=1\&UserID=0\& 


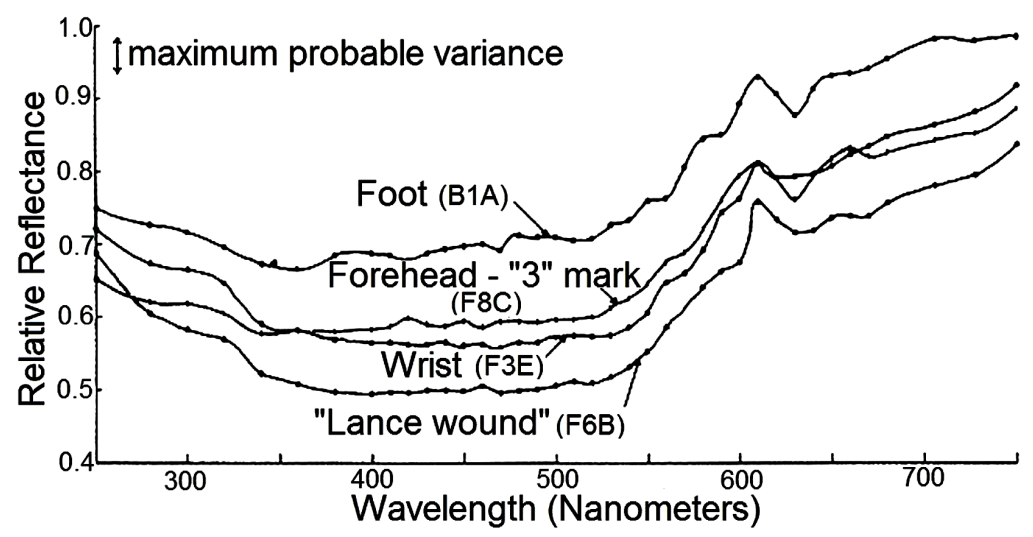

(a)

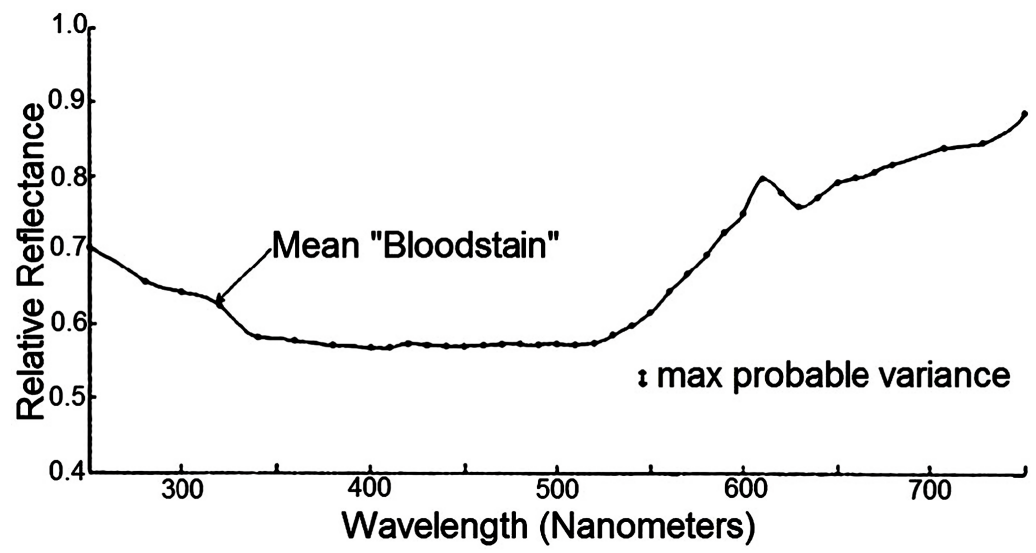

(b)

Figure S1. (a) Relative reflectance spectra of four Shroud bloodstains; (b) Mean relative reflectance values of four big bloodstains on the Shroud. From [12].

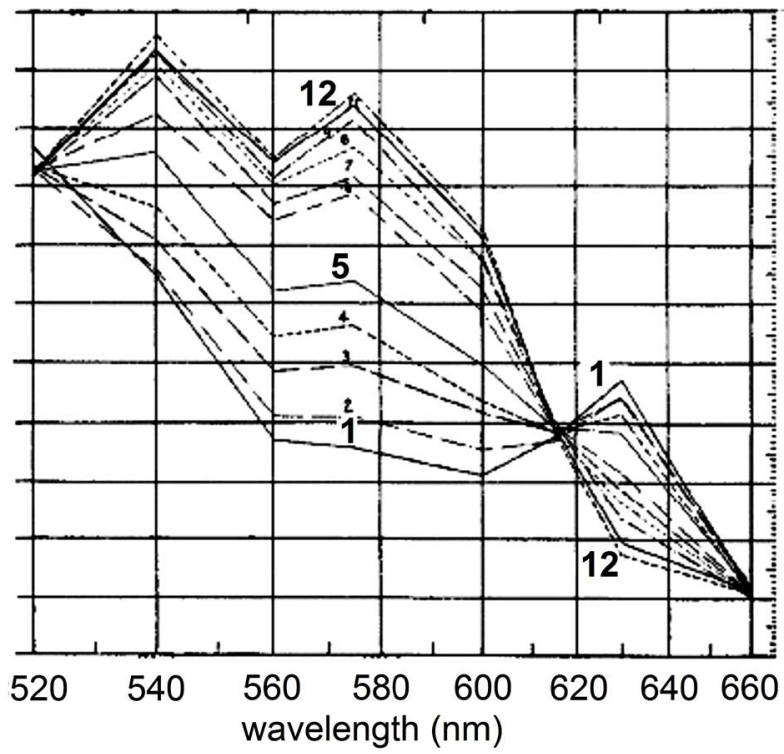

Figure S2. Absorbance of methemoglobin at pH 1 to 12 (mirrored figure). From [18 (c) the American Society for Biochemistry and Molecular Biology. 


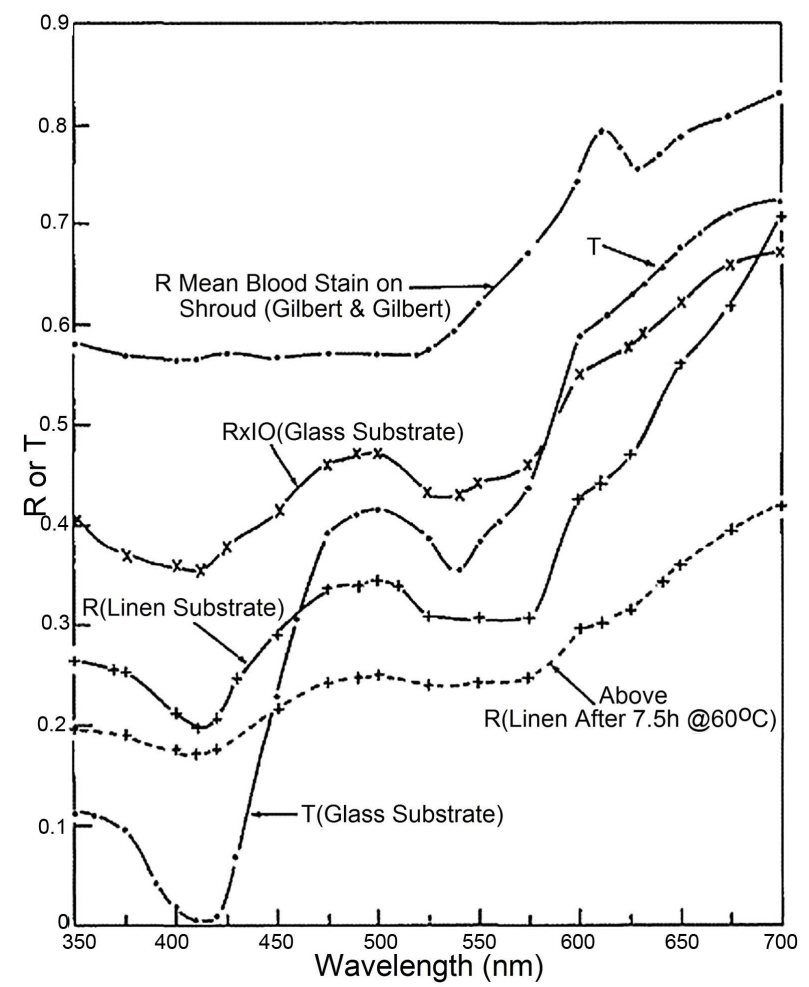

Figure S3. Integrated reflectance (R) and (one) transmission curve (T) for laboratory blood preparations, including Shroud blood reflectance values. From [19].

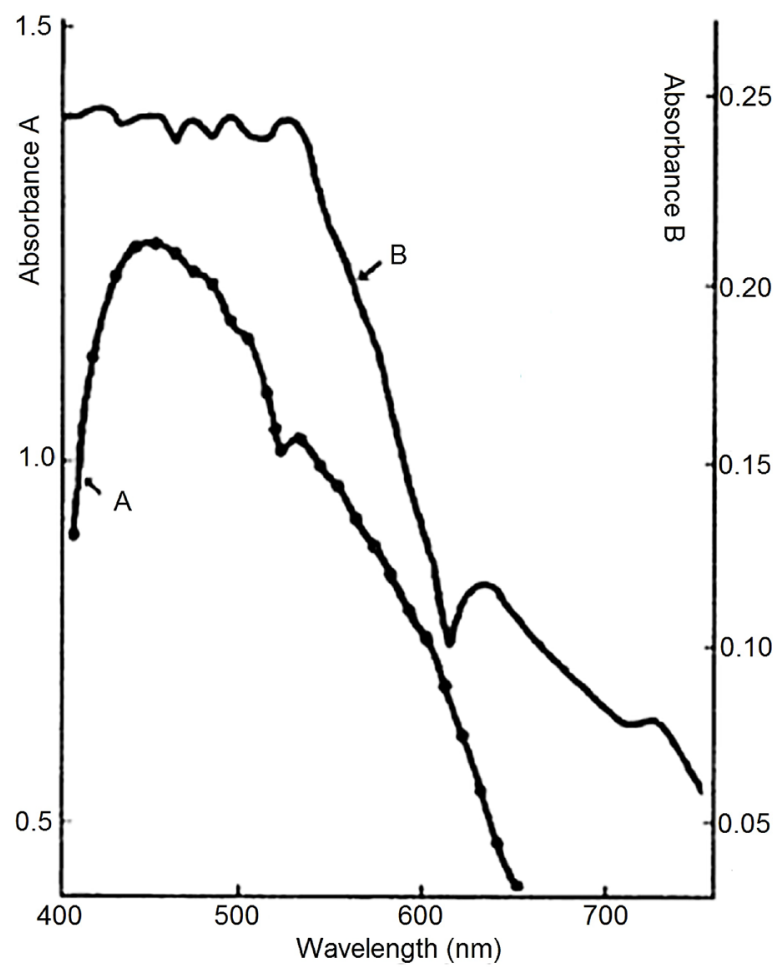

Figure S4. Absorbance spectra: A, of a brownish red stained fibril from one of the blood areas of the Shroud. B, spectrum obtained by transformation of the reflectance spectrum of the blood areas of the Shroud. From [6]. 


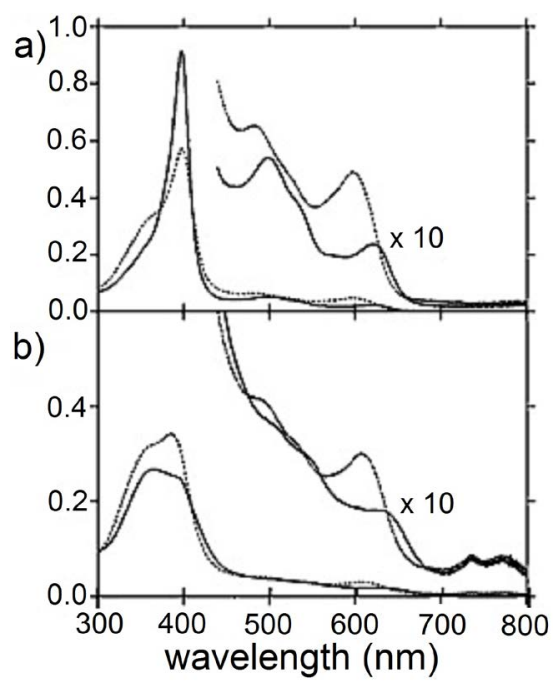

Figure S5. (a) Absorbance spectra of a buffered 1:4 water/methanol solution of heme monomer at pH 5.536 (solid line) and pH 8.862 (dotted line); (b) Absorbance spectra of a buffered aqueous solution of heme (dimer + a small monomer fraction) at pH 6.029 (solid line) and pH 9.669 (dotted line). From [20], with permission from Springer Science and Business Media.

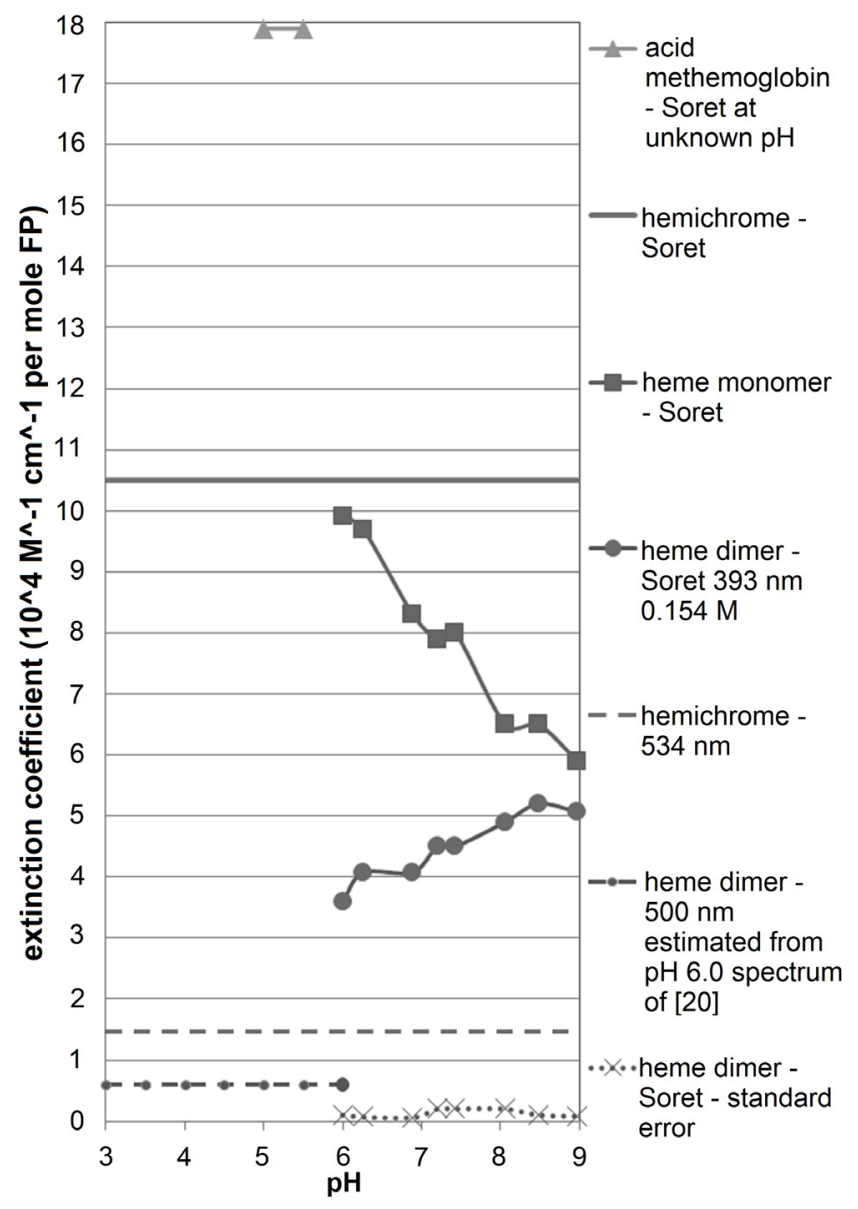

Figure S6. Extinction coefficients of various heme products vs $\mathrm{pH}$ (FP = Fe-protoporphyrin IX). Methemoglobin and hemichrome values from [21], heme monomer and heme dimer values from [20]. 


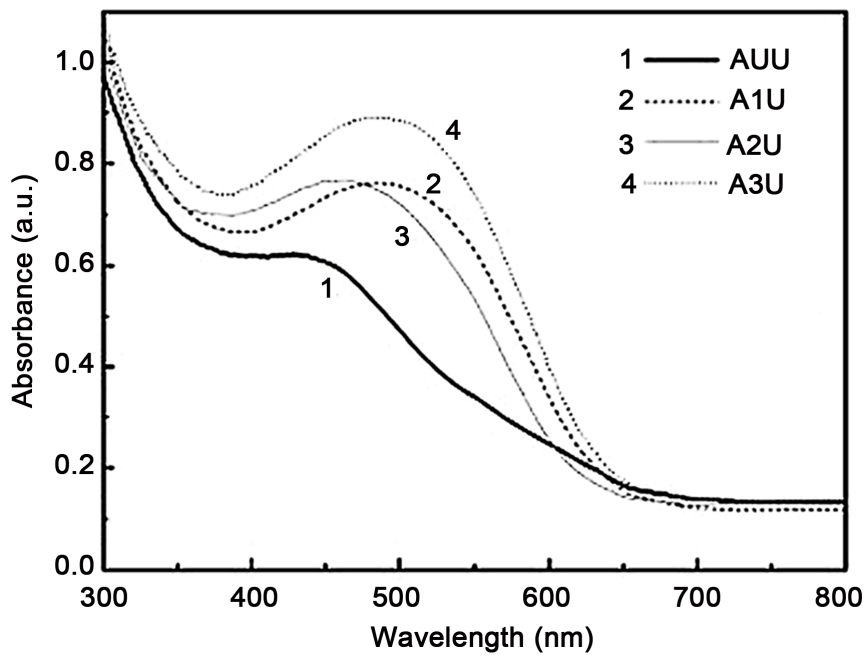

Figure S7. Absorbance of wool dyed with (probably neutral form of) alizarin without mordant (1) and mordanted red with three different mordants $(2,3,4)$. From [22] CElsevier.

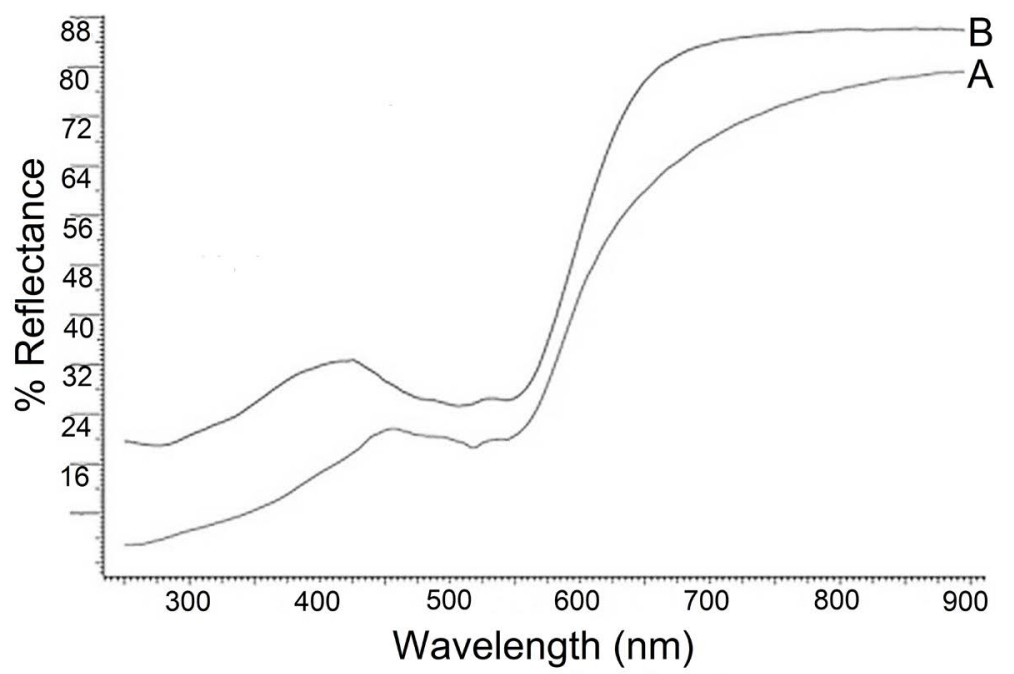

Figure S8. Reflectance spectra from a pink area of the 6th century AD manuscript Vienna Dioskurides, identified as madder lake (curve A), and of standard madder paint (curve B). From [23] (C)Elsevier.

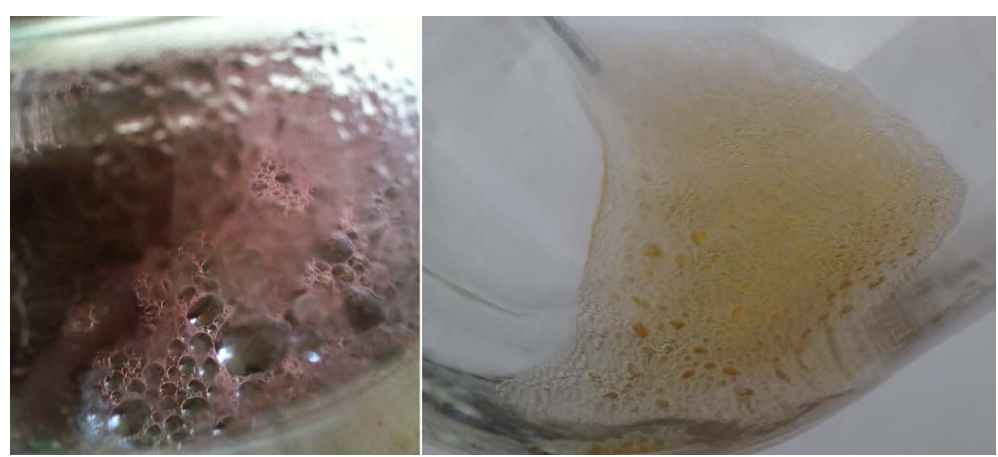

Figure S9. Stable foam arising from moderate stirring of madder root powder in hot tap water (left, pH 6 - 6.5) and from mild shaking of the same extract that had spontaneously acidified/fermented and then was acidified further by adding vinegar (right, $\mathrm{pH} \leq 4$ ). CA.A.M. v.d. Hoeven. 


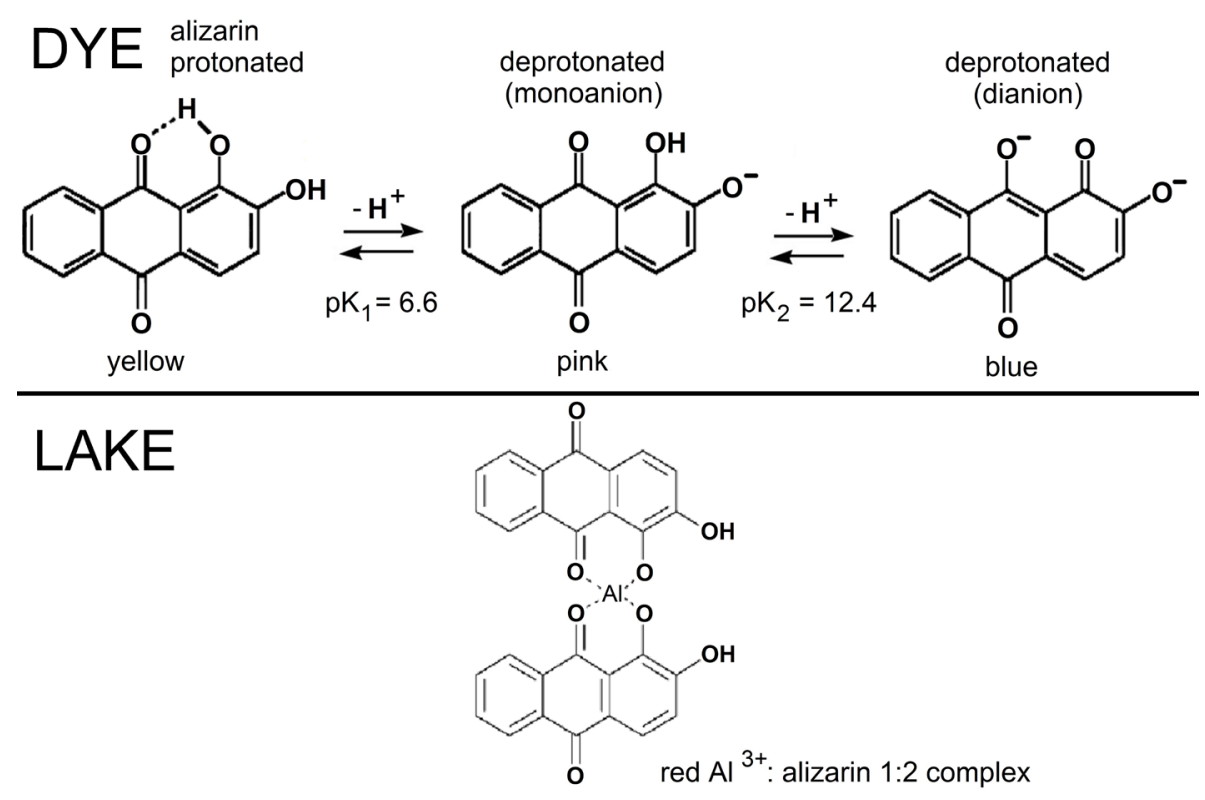

Figure S10. Molecular structure of the madder dyestuff alizarin (pKs and colors from [24]) and an example of an alizarin lake (from [30] C2008 Elsevier).

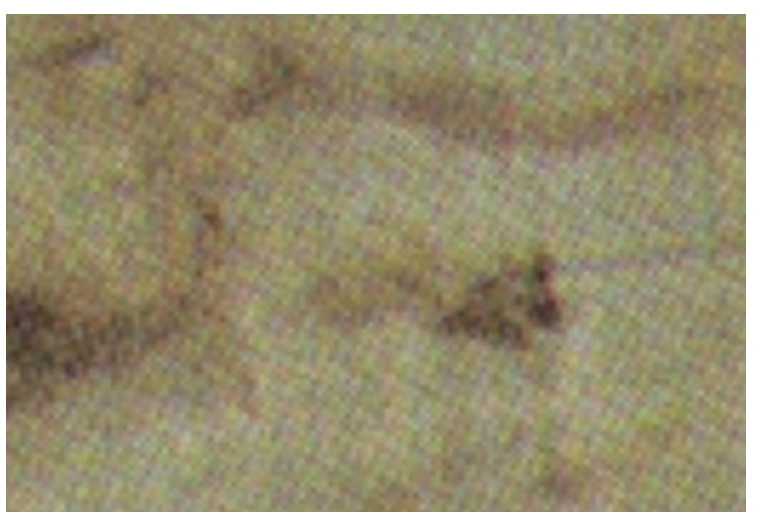

Figure S11. UV-fluorescence photo (cropped) of thin and dense blood flows in small of back area of the Shroud. From [27], with permission from the Biocommunications Association, Inc. (c)1981 Biocommunications Association, Inc.

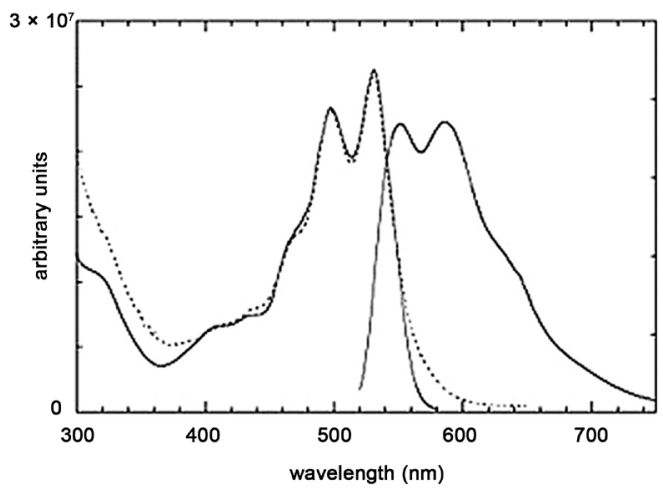

(a)

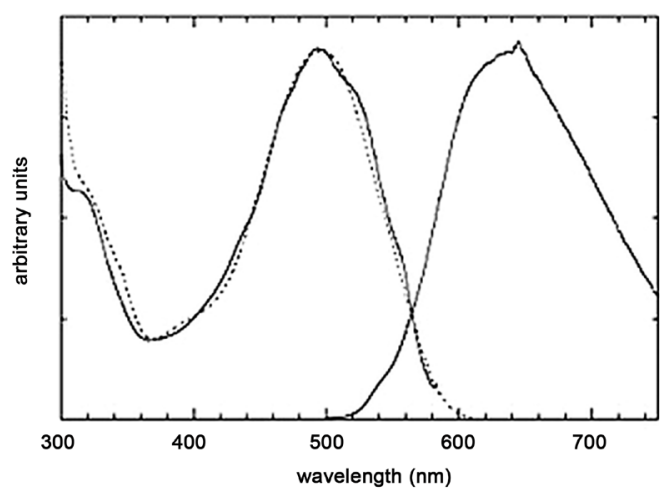

(b)

Figure S12. Fluorescence excitation (left) and emission spectra (right) of purpurin (a) and alizarin (b) aluminum complex in methanol/water solution (dotted line = absorption spectrum). From [30] (C2008 Elsevier. 


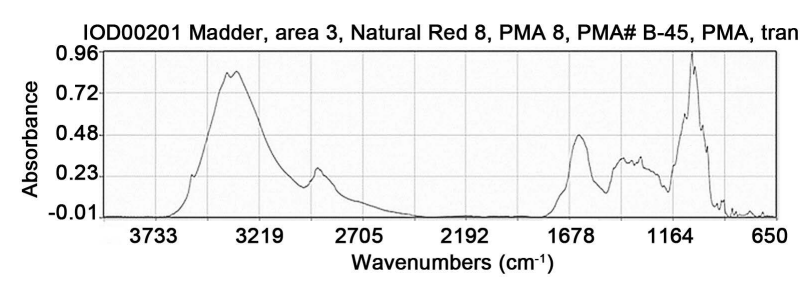

Figure S13. FT-IR spectrum of madder lake, IRUG Spectral Database, online interactive edition 2014. From [149], with permission from the Infrared \& Raman Users Group, www.irug.org.

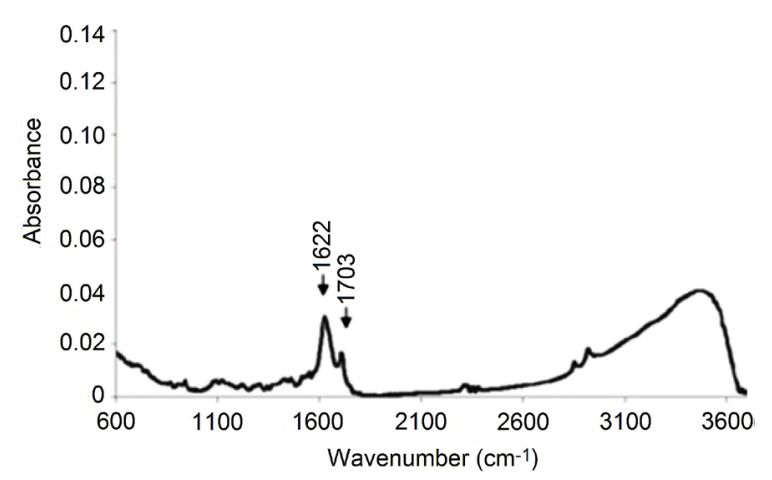

Figure S14. FT-IR spectrum of heme. From [33] (CAmerican Chemical Society.

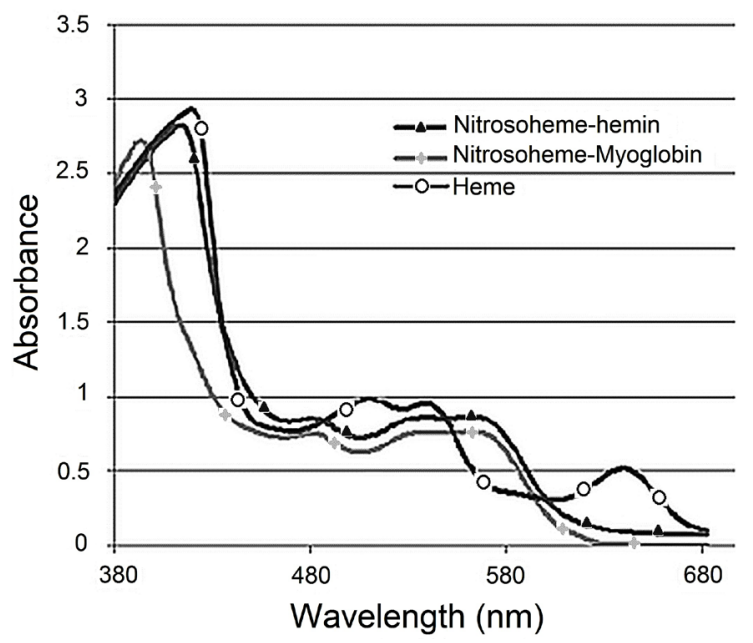

Figure S15. Absorbance of heme and of two nitrosohemes (made of hemin and myoglobin). From [33] (CAmerican Chemical Society.

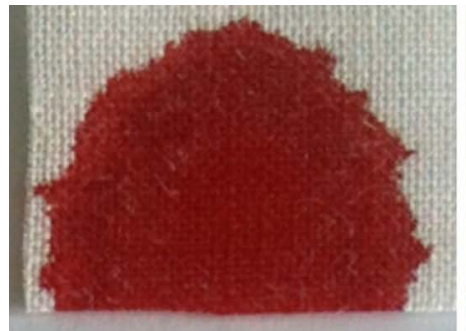

(a)

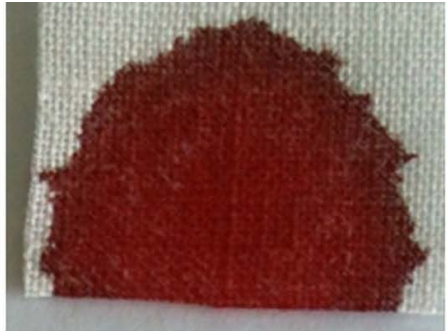

(b)

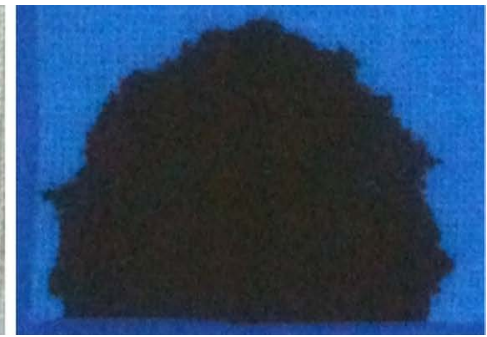

(c)

Figure S16. Fresh whole human blood fallen on horizontal linen straight from the finger does not produce a serum halo; (a) 3 min after staining; (b) 1 h after staining; (c) more than 26 days old-Wood lamp and L-42 UV filter (Hoya). CA.A.M. v.d. Hoeven. 


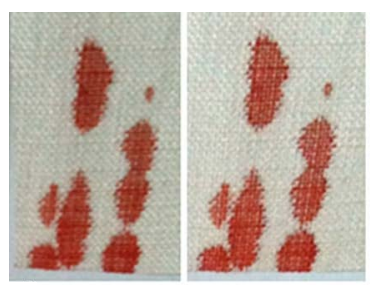

right after staining $5 \mathrm{~min}$ old

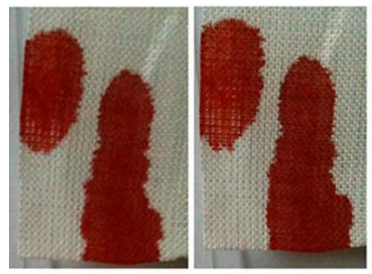

right after staining $<1 \mathrm{~min}$ old

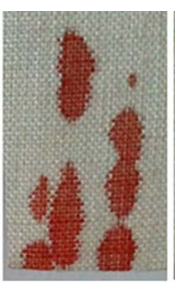

10 min old

(a)

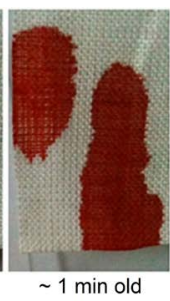

(b)
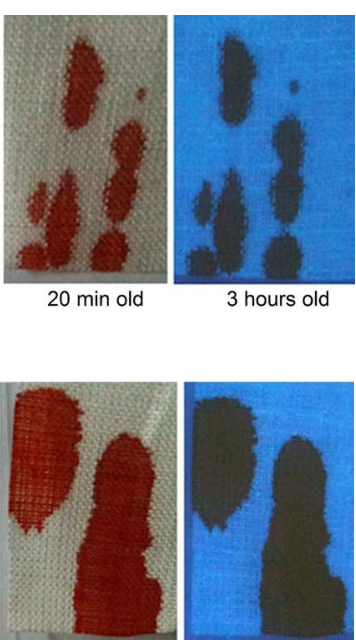

7 min old

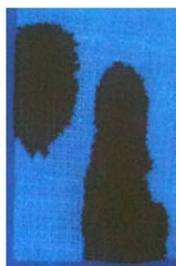

3 hours old

Figure S17. Vertical linen stained with fresh liquid whole human blood, straight from the finger, at $23^{\circ} \mathrm{C}-24^{\circ} \mathrm{C}, 60 \%-70 \%$ rel. humidity. (a) linen at $\sim 85^{\circ}$ from table, blood falling past cloth; (b) linen $\sim 70^{\circ}$ from table, bloody fingertip briefly touching one point of the cloth (left), blood falling on cloth (right). Last photos of rows: Wood lamp and L-42 UV filter (Hoya). CA.A.M. v.d. Hoeven.

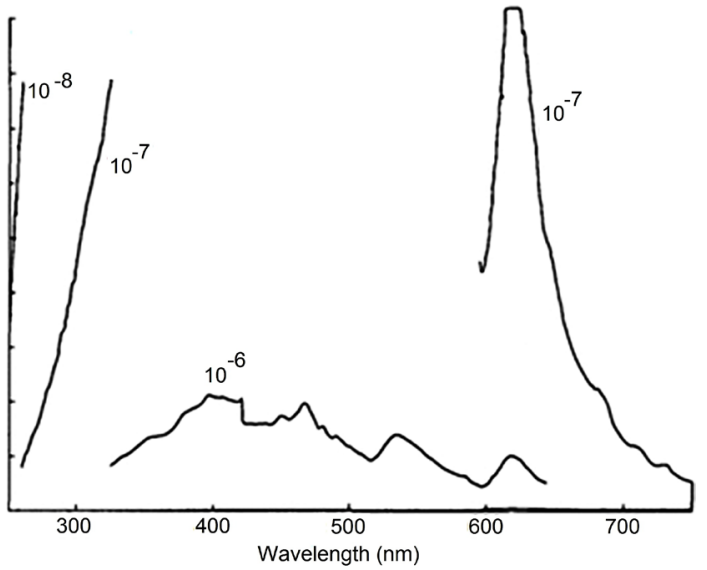

Figure S18. Raw reflectance scan of a clear area of the Shroud. From [12].

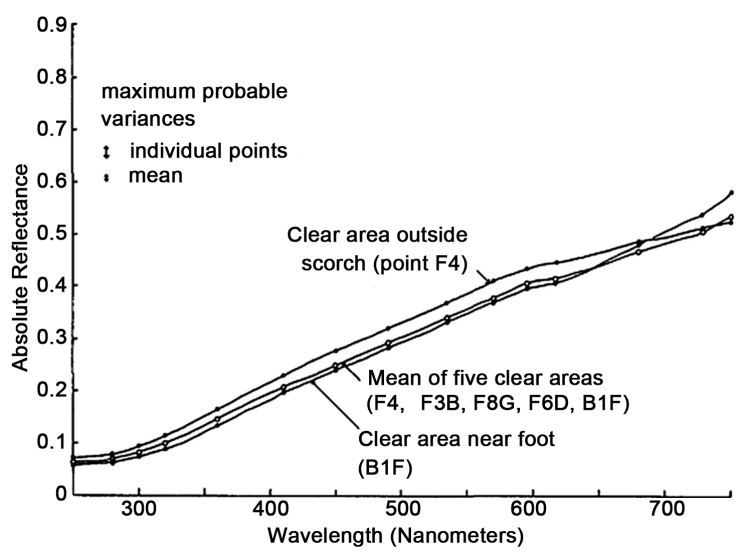

Figure S19. Absolute spectral reflectance (referred to magnesium oxide) of two clear unstained areas on the Shroud and the mean reflectance of five clear areas. From [12]. 


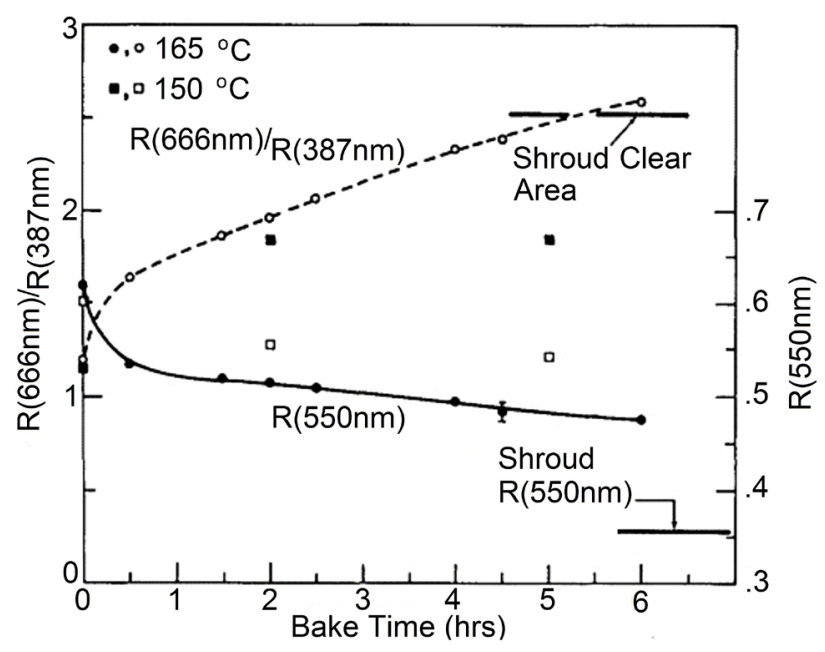

Figure S20. Comparison of color (represented by $\mathrm{R}(666 \mathrm{~nm}) / \mathrm{R}(387 \mathrm{~nm})$ ) and reflectance intensity at $550 \mathrm{~nm}(\mathrm{R}(550 \mathrm{~nm}))$ of the Shroud background and baked linen cloth. From [19].

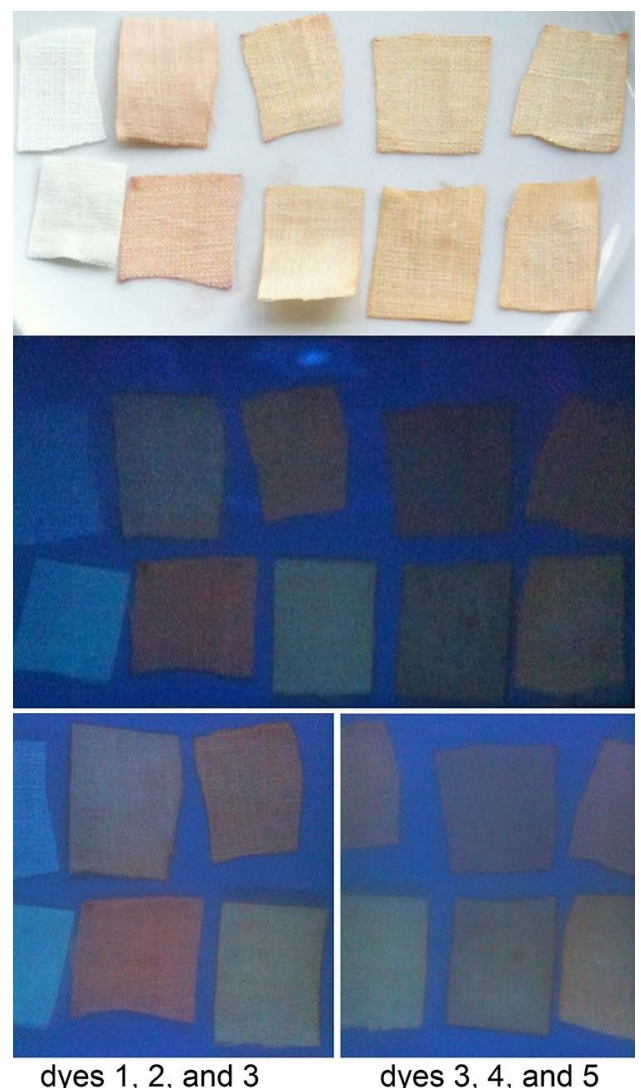

Figure S21. Ten pieces of oxygen-bleached linen dyed with different madder extracts. Five pieces in top rows: not-starched linen; five pieces in bottom rows: starched linen. Dyes from left to right, in both rows: 1 . no dye, 2 . root powder stirred in water at room temperature for $2 \mathrm{~h}$, then filtered, then acidified, 3. root powder stirred in hot water for ca. $45 \mathrm{~min}$, then filtered, then acidified, 4. root powder extracted as tea with boiling water, then spontaneously fermented, then acidified, 5. root powder extracted as tea with boiling water then acidified and stored. All dyes had a $\mathrm{pH} \leq 4$. All fluorescence photos taken through $2.5 \mathrm{~mm}$ thick L-42 UV-filter (Hoya), no filter in front of Wood lamp ( $365 \mathrm{~nm})$. Two bottom photos: left part and right part of the rows, photographed from smaller distances. (CA.A.M. v.d. Hoeven. 


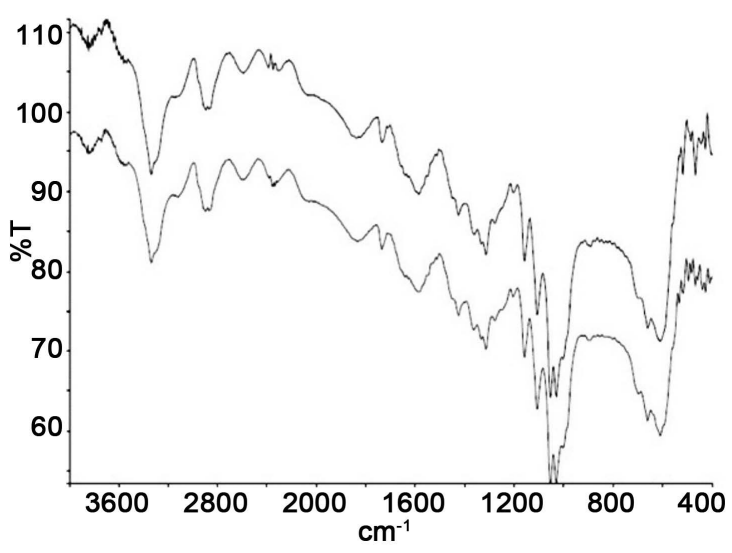

(a)

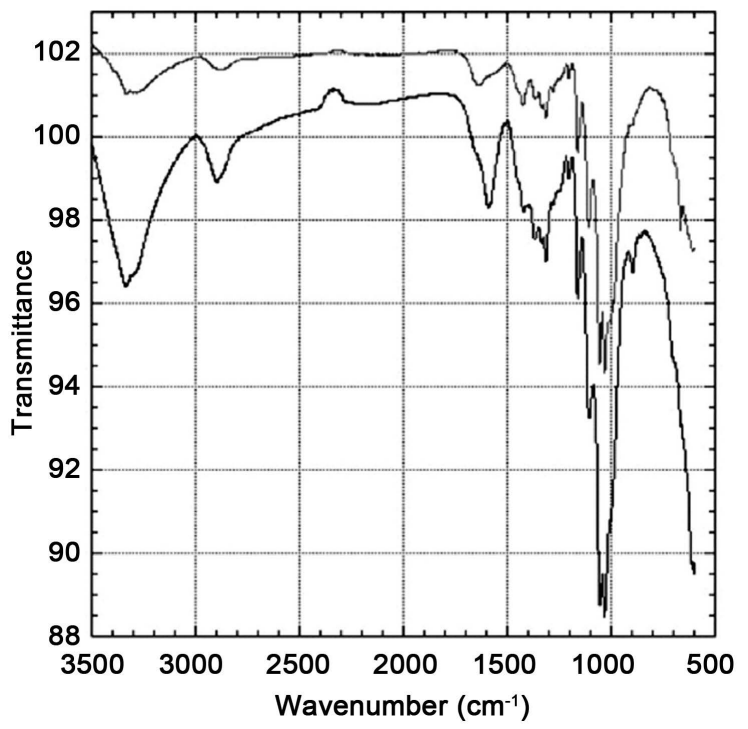

(b)

Figure S22. FT-IR ATR spectra of non-image fibers from (a) the Shroud's hands-image area and (b) a corner (upper gray curve) and of an image fiber (lower black curve). From [120]. Abscissas: wavenumbers in $\mathrm{cm}^{-1}$.

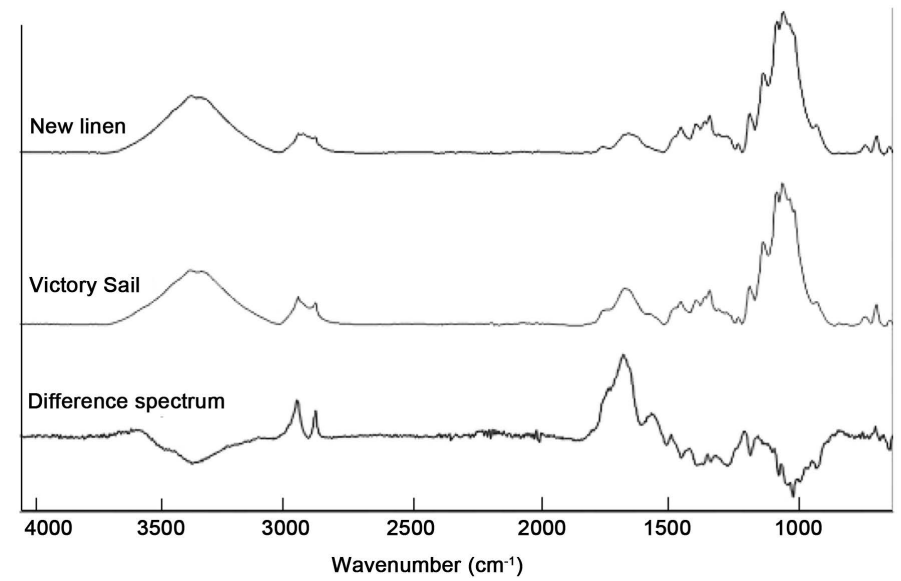

Figure S23. FT-IR spectra of new linen, the Victory sail, and their difference spectrum. From [126], with kind permission from P. Wyeth. 


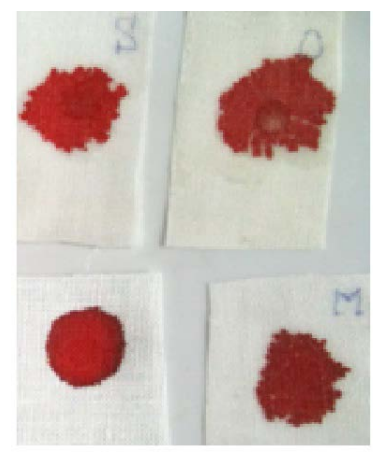

(a)

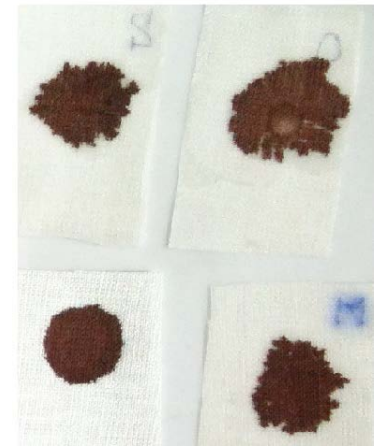

(c)

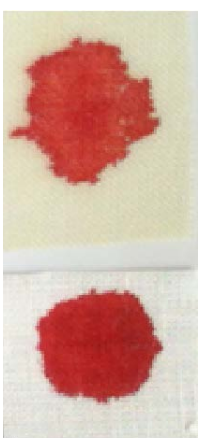

(b)

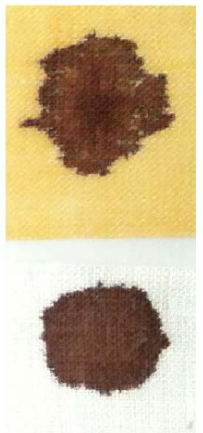

(d)

Figure S24. Pure linen soaked with oils, then bloodstained. (a) S = sesame oil, $\mathrm{O}=$ olive oil, $\mathrm{M}=$ microscopy immersion oil, blank = no oil; all 18 min stained; (b) top: myrrh oil, bottom: no oil, both just stained; (c) as in (a), but 3 weeks old; (d) as in (b), but 3 weeks old. (CA.A.M. v.d. Hoeven.

Table S1. Fluorescence intensities of various areas of the Shroud, derived from Figure 7, Figure 11, Figure 13, and Figure 17 of [12]. $\mathbf{F}_{\mathbf{4 5 0}}=$ fluorescence intensity at $450 \mathrm{~nm}, \mathbf{F}_{\mathbf{6 0 0}}=$ fluorescence intensity at $600 \mathrm{~nm}$, in arbitrary units of a scale variable.

\begin{tabular}{|c|c|c|c|c|c|}
\hline Area & Location (as labelled in [12]) & $\mathbf{F}_{450}$ & $F_{600}$ & $\begin{array}{c}\text { Ratio } \\
\mathbf{F}_{450} / \mathbf{F}_{600}\end{array}$ & $\begin{array}{c}\text { Mean ratio } \\
\mathbf{F}_{450} / \mathbf{F}_{600}\end{array}$ \\
\hline \multirow{4}{*}{ Background } & $\mathrm{F} 4$ & 0.354 & 0.118 & 3.00 & \multirow{4}{*}{2.98} \\
\hline & F3B & 0.318 & 0.107 & 2.97 & \\
\hline & F6D & 0.277 & 0.097 & 2.86 & \\
\hline & B1F & 0.255 & 0.082 & 3.11 & \\
\hline \multirow{4}{*}{ Image } & Calf B1E & 0.282 & 0.104 & 2.71 & \multirow{4}{*}{2.55} \\
\hline & Neck B6A & 0.247 & 0.100 & 2.47 & \\
\hline & Nose F8F & 0.195 & 0.087 & 2.24 & \\
\hline & Heel B1D & 0.165 & 0.059 & 2.80 & \\
\hline \multirow{3}{*}{$\begin{array}{l}\text { Blood } \\
\text { stain }\end{array}$} & Forehead-“3” mark F8C & 0.178 & 0.075 & 2.37 & \multirow{3}{*}{2.29} \\
\hline & Wrist F3E & 0.142 & 0.063 & 2.27 & \\
\hline & “Lance Wound” F6B & 0.125 & 0.056 & 2.23 & \\
\hline \multirow{5}{*}{ Scorch } & B3E & 0.217 & 0.117 & 1.85 & \multirow{5}{*}{1.64} \\
\hline & $\mathrm{F} 8 \mathrm{H}$ & 0.203 & 0.094 & 2.16 & \\
\hline & F3C & 0.150 & 0.078 & 1.92 & \\
\hline & B1C & 0.106 & 0.096 & 1.10 & \\
\hline & F3D & 0.056 & 0.049 & 1.14 & \\
\hline
\end{tabular}

